
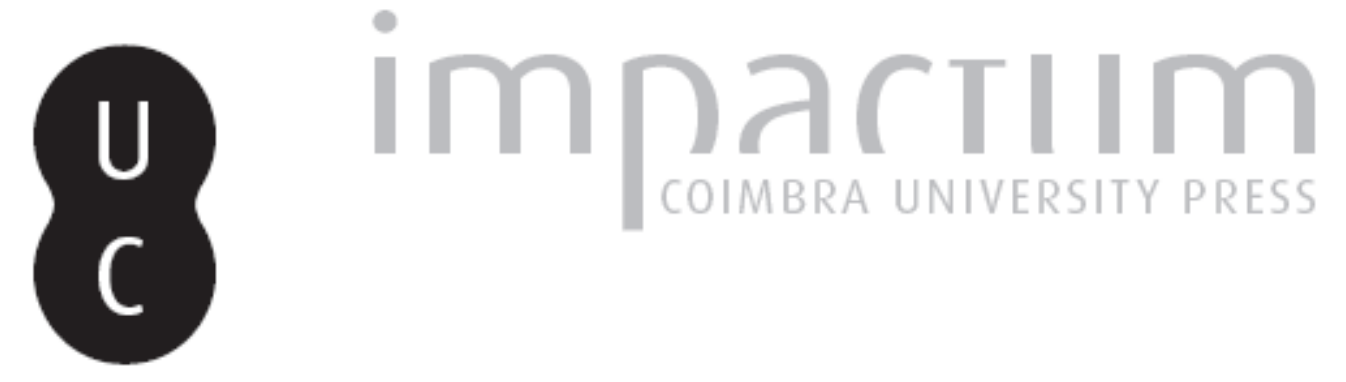

\title{
A indústria oleícola de Lisboa na segunda metade do século XVI: o Regimento dos lagareiros dos lagares de azeite de 1572 e os capítulos que se lhe acrescentaram em 1575
}

Autor(es): $\quad$ Marreiros, Rosa

Publicado por: Imprensa da Universidade de Coimbra

URL

persistente:

URI:http://hdl.handle.net/10316.2/45005

DOI:

DOI:https://doi.org/10.14195/0870-4147_38_10

Accessed : $\quad$ 26-Apr-2023 10:39:00

A navegação consulta e descarregamento dos títulos inseridos nas Bibliotecas Digitais UC Digitalis, UC Pombalina e UC Impactum, pressupõem a aceitação plena e sem reservas dos Termos e Condições de Uso destas Bibliotecas Digitais, disponíveis em https://digitalis.uc.pt/pt-pt/termos.

Conforme exposto nos referidos Termos e Condições de Uso, o descarregamento de títulos de acesso restrito requer uma licença válida de autorização devendo o utilizador aceder ao(s) documento(s) a partir de um endereço de IP da instituição detentora da supramencionada licença.

Ao utilizador é apenas permitido o descarregamento para uso pessoal, pelo que o emprego do(s) título(s) descarregado(s) para outro fim, designadamente comercial, carece de autorização do respetivo autor ou editor da obra.

Na medida em que todas as obras da UC Digitalis se encontram protegidas pelo Código do Direito de Autor e Direitos Conexos e demais legislação aplicável, toda a cópia, parcial ou total, deste documento, nos casos em que é legalmente admitida, deverá conter ou fazer-se acompanhar por este aviso. 

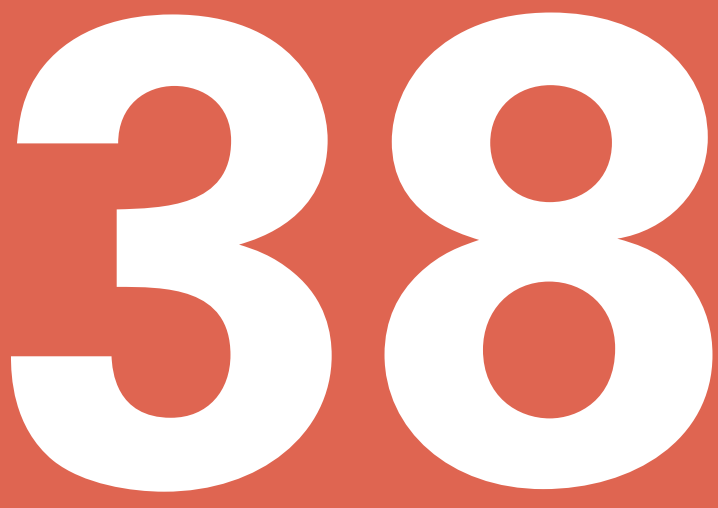

\section{Revista Portuguesa de História}

Faculdade de Letras da Universidade de Coimbra Instituto de História Económica e Social

Coimbra 08 


\section{A indústria oleícola de Lisboa na segunda metade do século XVI: O Regimento dos lagareiros dos lagares de azeite de 1572 e os capítulos que se lhe acrescentaram em 1575}

Rosa Marreiros

Faculdade de Letras da Universidade de Coimbra

\section{Introdução}

Ao Regimento dos lagareiros dos lagares de azeite de Lisboa de 1572, que se encontra copiado no Livro dos Regimentos dos officiaes mecanicos da mui excelente e sempre leal cidade de Lixboa refromados per ordenança do Illustrissimo Senado della pello $L^{d o}$ Duarte Nunez do Liam ${ }^{1}$. Anno. MDLXXIJ $^{2}$, foi acrescentada, em data posterior e noutro tipo de letra, a seguir

1 Ou de Lião, conforme vemos na introdução do Regimento dos selleiros e fusteiros de 24 de Janeiro de 1572, publicado na íntegra por Franz-Paul Langhans, em Corporações dos oficios mecânicos. Subsídios para a sua história, volume segundo, Lisboa, Imprensa Nacional de Lisboa, 1943, pp. 575-576 (vide infra, p. 269, nota 10, onde transcrevemos grande parte do seu conteúdo).

2 Esta importante fonte para a história das corporações portuguesas, que hoje se encontra no Arquivo Histórico da Câmara Municipal de Lisboa, foi publicada pelo Dr. Vergílio Correia, embora com muitos dos seus regimentos truncados, sob o título de Livro dos Regimẽtos dos Officiaes mecanicos da mui nobre e sẽpre leal cidade de Lixboa (1572), Coimbra, Imprensa da Universidade, 1926. O Regimento dos lagareiros dos lagares de azeite encontra-se nas páginas 181 a 186 desta edição. O Livro dos Regimẽtos dos officiaes mecanicos (a partir de agora indicado pela sigla $L R O M$ nas notas de rodapé) foi o resultado da reforma e compilação dos 
ao respectivo título, a seguinte informação: "Aas folhas 322 stão hũas adições a este Regimento" 3 . Esta nota tinha em vista alertar os oficiais camarários para umas adições que, entretanto, haviam sido feitas a este documento e facilitar a sua localização, sempre que fosse necessário consultá-las, ou copiálas. Simplesmente, o facto de elas não se encontrarem registadas no referido códice e de este ter apenas 316 folhas levou alguns autores a aventar a hipótese de se terem perdido, ou suprimido, as suas últimas folhas, anteriormente à sua encadernação ${ }^{4}$. O desconhecimento do seu paradeiro levou Franz-Paul Langhans a admitir, igualmente, que estas adições não tivessem chegado a ser compiladas 5 .

Se a primeira hipótese - perda ou supressão das últimas folhas ou caderno do Livro dos Regimentos dos officiaes mecanicos anteriormente à sua encadernação - era plausível, o mesmo já não acontecia em relação à segunda suposição aventada. Na verdade, não parece crível que alguém anotasse algures num códice o número da folha de registo de um documento antes de este documento estar compilado, e nele lançado. No caso em questão, se nos remetem para a folha

regimentos dos ofícios mecânicos de Lisboa, levadas a cabo pelo Licenciado Duarte Nunes de Lião por incumbência da Câmara desta cidade, em data que desconhecemos, mas que Marcello Caetano admite ter sido entre 1569 e 1571 (vide "A antiga organização dos mesteres da cidade de Lisboa", em Franz-Paul Langhans, ob. cit., volume primeiro, pp. XVIII e XIX). Em carta de 10/XII/1572, dirigida por D. Sebastião aos vereadores da Câmara de Lisboa, o monarca exprime o contentamento que lhe deu o conteúdo de uma carta por eles enviada, onde davam conta do "bom estado da saude e abastecimento da cidade, e de se achar esta quasi livre das dividas que contrahira durante a epidemia [de 1569-1570]", e também a "ordem que deram no reduzir das posturas municipaes em um só livro, e nos regimentos que fizeram para os officios mechanicos" (vide Eduardo Freire de Oliveira, Elementos para a história do Município de Lisboa, $1^{\text {a }}$ Parte, t. I, Lisboa, Typographia Universal (Imprensa da Casa Real), 1887, p. 587, onde se transcreve parte dela). Nesta altura, desempenhavam as funções de vereadores da Câmara D. Duarte da Costa e o Dr. António Dias, ambos do Conselho do rei (LROM, Regimento dos Espadeiros / Vergílio Correia, ob. cit., pp. XVII-XVIII).

3 Vide LROM, fl. 224v (publ. em fac-simile por F.-P. Langhans, "Apontamentos para a história do azeite em Portugal”, Lisboa, sep. Boletim da Junta Nacional do azeite, Lisboa, 1949, entre as páginas pp. 94-95 deste seu estudo).

4 F.-P. Langhans, ob. cit., pp. 96-97, e Artur Salvado, "Alguns documentos para o estudo evolutivo da indústria oleícola portuguesa. Regimentos e posturas sobre lagareiros e lagares de azeite”, sep. Boletim da Junta Nacional do Azeite, 1959, pp. 64-65. F.-P. Langhans admite a hipótese destas folhas terem sido suprimidas no reinado de D. João V, ou seja, na altura em que se procedeu à encadernação de muitos livros do arquivo da Câmara de Lisboa (ob. cit., pp. 96-97). Esta hipótese só nos parece plausível no caso dos últimos fólios deste livro se encontrarem em mau estado de conservação, não valendo a pena conservá-los.

5 Ob. cit., p. 96. 
322 do dito códice é porque nela (ou a partir dela) se encontravam registadas as ditas adições.

Se o registo destas adições pode levantar dúvidas, uma vez que falta a folha do livro onde se diz terem sido lançadas, o mesmo já não acontece no tocante à sua compilação. As adições ao Regimento dos lagareiros dos lagares de azeite de 1572 foram, efectivamente, compiladas. Uma cópia deste regimento, datada de 10 de Novembro de 1575, que se tirou para o lagar de Maria Monteiro, localizado na rua que ia das Escolas Gerais para o mosteiro de S. Vicente de Fora, tem apenso os capítulos que se vieram a acrescentar em 17 de Outubro de $1575^{6}$. Na respectiva introdução, diz-se que, neste dia, na Câmara da Vereação, estando aí presentes o presidente, os vereadores e alguns oficiais ${ }^{7}$, se procedeu à revisão do Regimento dos lagareiros dos lagares de azeite e à análise dos "apontamentos" que se haviam mandado fazer sobre este assunto aos juizes dos limites, com a anuência do povo. A aplicação deste regulamento deve ter revelado algumas deficiências, nomeadamente, no tocante ao furto de azeite nos lagares, deficiências essas que a Câmara de Lisboa, com a colaboração do povo, tentou colmatar.

Na reunião de 17 de Outubro, analisaram-se as questões levantadas, bem como as propostas de solução apresentadas para elas, e no final foram redigidos doze capítulos, de que mais adiante falaremos, que passaram a andar anexados às cópias do Regimento dos lagareiros dos lagares de azeite de 1572: "e este regimento, com ho de que atee guora se usou, se dara encorporado a cada mestre de laguar". E foi, precisamente, o que se verificou em relação à cópia que se tirou para o lagar de Maria Monteiro, assinada por Nuno Fernandes de Magalhães, que na altura desempenhava o cargo de escrivão da Câmara. Embora no passo que citámos atrás se fale em "regimento", trata-se, no entanto, de um conjunto de capítulos que se acrescentou ao Regimento dos lagareiros dos lagares de azeite de 1572, conforme se informa no respectivo título: Capitullos que se acrecentarão ao Regimento dos laguareiros.

6 IAN/TT - Mosteiro de S. Vicente de Fora, $2^{\text {a }}$ incorporação, cx. 9, L-1746.

7 O documento que estamos a analisar não indica os seus nomes, mas nós sabemos, por uma outra fonte, que nela estiveram presentes o seu presidente, na altura, D. Duarte da Costa, que fora governador do Brasil nos anos de 1553 a 1558; os vereadores Miguel Cabedo de Vasconcelos, Simão Cabral e Fernão de Pina, todos eles letrados e de nomeação régia; Álvaro de Morais, procurador da cidade (o segundo procurador, Sebastião de Lucena, parece não ter estado presente nesta sessão); e Dinis Coelho, Álvaro Esteves, António Pires e Estêvão Fernandes, procuradores da Casa dos Vinte e Quatro (Vide Paul-Franz Langhans, As corporações dos ofícios mecânicos, volume primeiro, pp. 269-270). 
Como todos os lagares de azeite da cidade e redondezas de Lisboa, a partir desta data, passaram a ser obrigados a ter uma cópia deste regimento, com os respectivos aditamentos, afixada à porta de entrada, e estes se encontrassem separados por quase cem folhas no Livro dos Regimentos dos officiaes mecanicos, optou-se por indicar, no início do regimento, a folha onde eles se encontravam, a fim de facilitar a tarefa da sua localização aos escrivão da Câmara, quando este tivesse de os consultar ou copiar. Por esta razão, estamos convictos da existência dos aditamentos aludidos a partir da folha 322 deste códice, conforme alguém teve o cuidado de anotar a seguir ao título do regimento dos lagareiros.

\section{O Regimento de 1572}

O Regimento dos lagareiros dos lagares de azeite de Lisboa de 1572 encontra-se entre os três regimentos de lagareiros mais antigos chegados até nós (ou de que temos conhecimento), figurando ao lado de o de Évora, de $1392^{8}$, e de o de Coimbra e termo, de $1554^{9}$. De todos, foi o que nos pareceu ser o mais perfeito, no ponto de vista organizativo.

Compõe-se de 16 capítulos com várias disposições reguladoras da indústria da moagem da azeitona em Lisboa e termo. É provável que muitas das suas disposições já fossem observadas por imposição do direito costumeiro ou da Câmara, mas só agora, devido a uma política de âmbito mais geral, por esta levada a cabo, e que visava a arregimentação dos principais mesteres da cidade - tarefa de que viria a ser incumbido o licenciado Duarte Nunes de Lião -,

8 O regimento de Évora limita-se a um reduzido número de disposições sobre os seus lagares de azeite, incluídas no Regimento da cidade deste ano, ou próximo dele. Essas disposições dizem respeito à obrigatoriedade de os lagareiros terem as talhas fechadas, quando nelas estivesse azeite dos fregueses dos lagares; à capacidade da moedura de azeitona, que devia ser de 12 fangas (vinte e quatro alqueires), medidas pela fanga direita; ao custo da moedura de azeitona, que variava de acordo com a tipologia dos lagares, de sertã ou de calda; e ao destino da água ruça, que não podia ir ter às fontes, "a qual cousa seria gram perjuiso aas fontes e auguas dellas, e jentes que as ham de bever" (Regimento da cidade, cap. XXIV - $T^{o}$ dos lagares do azeite, publ. por Gabriel Pereira, Documentos históricos da cidade de Évora, Primeira Parte, Evora, Typographia da Casa Pia, 1885, p. 183).

9 Vide Regimẽto dos lagares d'azeyte desta cydade e seu termo per que usão e se regem e do que hão-de levar de maquia por fazer e lavrar os azeyttes, em Livro da Correa ou Livro de regimentos e posturas desta muy nobre e sempre leal cidade de Coimbra, 1, publ. por J. Pinto Loureiro com o título de Livro I da Correa (Legislação quinhentista do Município de Coimbra), Coimbra, Edição da Biblioteca Municipal, 1938, pp. 1-16. A partir de agora, passaremos a indicar esta fonte pela sigla $L C, 1$. 
terão sido reunidas num estatuto próprio, regulador desta indústria e da profissão de lagareiro ${ }^{10}$.

As normas nele contidas dizem respeito ao pessoal que trabalhava nos lagares (mestre, moedor e acarretador); à medição, acondicionamento e à moagem da azeitona; ao acondicionamento do azeite e ao seu desvio nos lagares; à manutenção da moral e da disciplina no interior destas instalações; e à fiscalização da actividade dos lagareiros, bem como às penas impostas aos que violassem as suas disposições. Em todos os lagares devia haver uma cópia deste regimento, "em taboas pemdurado, pera se poder ver e o leerem todas as pessoas que a elles forem", sob pena do pagamento de uma multa de 2000 réis $^{11}$.

As afinidades existentes entre algumas das suas disposições e as do Regimento dos lagares d'azeyte de Coimbra e termo, de 1554, leva-nos a admitir a hipótese de que este útimo possa ter servido de modelo.

\section{Normas relativas ao pessoal que trabalhava nos lagares}

De acordo com este regimento, nos lagares de azeite de Lisboa e termo havia três categorias de trabalhadores: o mestre, o moedor e o acarretador.

\footnotetext{
${ }^{10} \mathrm{Na}$ acta da reunião da Câmara de Lisboa de 24/I/1572, em que se aprovaram os regimentos reformados por Duarte Nunes de Lião, e que aparece como introdução em alguns regimentos lioninos, indicam-se os motivos que levaram o senado da Câmara a encarregar este legista de tal tarefa. De acordo com o seu conteúdo, nesta reunião "se tratou dos muitos Inconuenientes que se seguião de muitos officiaes mecanicos desta cidade não terem regimentos [ate hora perque se governassem, e dos regimentos] que erão dados a alguns officiaes serem muitos delles tão antigos e desordenados assi a cerca das examinações como de outras cousas tocantes a seus officios que nestes tempos não seruião e em todos elles não Irem jnseridas muitas posturas que sobre os ditos seus officios a cidade tinha feitas. Pelo que os ditos officiaes não erão visitados nem executados polos erros que fazião como era necessario, o que era contra serviço de Deus e bem do pouo. E considerando que huma das cousas mais jmportantes ao gouerno da republica são os regimentos dos officiaes e o comprimento e execução delles, acordarão de dar nouos regimentos aos officiaes a que ate hora não forão dados e de reformar os antigos pela maneira que conuinha ao bem comuon. Pelo que encarregarão ao Licenciado Duarte Nunez de Lião que juntamente com a reformação das posturas desta cidade que fazia per ordenança della reformasse e ordenasse os ditos regimentos. Os quaes sendo feitos com diligencia e boom exame forão vistos e approuados pelos sobre ditos Vereadores e procuradores e mandarão que se comprissem como se nelles conteem [...]" (Regimento dos selleiros e fusteiros de 24 de Janeiro de 1572, publ. integralmente por F.-P. Langhans, As Corporações dos oficios mecânicos, volume segundo, pp. 575-576).

${ }^{11}$ Reg. ${ }^{o} 1572$, cap. 16 (Ap. Doc., p. 313).
} 
É provável que, nos lagares com mais de duas prensas de varas e um moinho, o número de obreiros, que nele trabalhavam, fosse além destes três ${ }^{12}$.

$\mathrm{O}$ mestre era o mais categorizado de todos. Ao contrário do que poderíamos supor, o principal responsável pela laboração, administração e guarda do lagar não era o proprietário ou o rendeiro, e sim a pessoa do mestre. Para desempenhar esta função, precisava de possuir carta de mestre, prestar juramento na Câmara e apresentar fiadores idóneos ${ }^{13}$. A carta de mestre só a poderia obter na Câmara de Lisboa depois de se submeter ao exame de mestria e de nele ter sido aprovado.

Todos os anos, antes da abertura dos lagares de azeite, a Câmara nomeava dois oficiais lagareiros, "boons omeis e sufficiemtes em seu officio", para examinadores dos candidatos a mestres lagareiros e "visitarem" estas instalações, em missão de vistoria ${ }^{14}$. Nenhum deles podia examinar "per si soo official algũm, senão sendo ambos juntos cõ o escriuão de seu cargo", conforme mandava uma postura camarária de âmbito geral, aplicável aos "examinadores de qualq[ue]r officio"15. A estes examinadores-vedores, era exigido um juramento sobre os Santos Evangelhos, prestado na Câmara, de que bem cumpririam as suas funções ${ }^{16}$. Marcello Caetano, no seu estudo sobre "A antiga organização dos

${ }^{12}$ No que diz respeito aos colaboradores do mestre, o Regimento dos lagares d'azeyte de Coimbra e termo de 1554 exigia, num dos seus artigos, que os donos dos lagares (ou os seus rendeiros) tivessem neles "mamcebos" em abastança para o "fazimento dos azeites" e outros serviços, de modo a não ser necessário que os donos da azeitona enviassem para eles os seus servidores (LC, 1, Regimento dos lagares d'azeyte, cap. 25 / J. Pinto Loureiro, ob. cit., p. 9). Sobre o pessoal que trabalhava nos lagares de azeite desta cidade e termo, vide também António de Oliveira, A vida económica e social de Coimbra de 1537 a 1640, primeira parte, vol. I, Coimbra, Instituto de Estudos Históricos Dr. António de Vasconcelos, 1971, pp. 508-510, e Sérgio Cunha Soares, O Município de Coimbra da Restauração ao Pombalismo, vol. I, Coimbra, Centro de História da Sociedade e da Cultura da Faculdade de Letras da Universidade de Coimbra, 2001, pp. 74-78.

${ }^{13} \mathrm{Na}$ antiga organização dos ofícios, o desempenho de uma actividade, considerada capital para a comunidade, implicava a prestação de uma prova, prova essa que tinha lugar perante dois especialistas do mester que se pretendia exercer, nomeados e ajuramentados para este efeito. Sem a prestação deste exame (com aprovação), ninguém podia, nesta altura, exercer um ofício considerado fundamental e que requeresse um elevado grau de perícia. Sobre a organização dos ofícios mecânicos neste período, vide F.-P. Langhans, As corporações dos oficios mecânicos, vols I e II.

${ }^{14}$ Em Coimbra (e decerto também em Lisboa e noutras terras), os lagares de azeite não podiam entrar em laboração sem uma prévia vistoria por parte da Câmara, requerida pelos respectivos proprietários ou arrendatários (Vide António de Oliveira, ob. cit., vol. I, pp. 506-507).

${ }^{15}$ Vide LROM, Livro segvndo de posturas geraes para os officiaes mecanicos, cap. XIII - Que os examinadores não examinẽ per si soos senão juntos (Vergílio Correia, ob. cit., pp. 239-240).

${ }^{16}$ Reg. ${ }^{\circ}$ 1572, Introdução (Ap. Doc., p. 309). 
mesteres da cidade de Lisboa", realça a função destes examinadores, dizendo que "era importantíssima, porque dela dependia a observância do disposto quanto ao exame de mestria e a justiça na admissão de novos mestres" ${ }^{17}$.

O exame de mestria, "por pratiqua", era, contrariamente ao que poderíamos supor, de natureza teórica, incidindo as perguntas dos examinadores sobre situações concretas, relacionadas com a função de mestre lagareiro ${ }^{18}$. Em caso de aprovação, o candidato a mestre recebia uma certidão do exame, passada por um escrivão oficial da Câmara e por eles, examinadores, assinada, onde se declarava que era "abil e sufficiemte pera o dito oficio". Se reprovasse, é provável que só no ano seguinte, antes da abertura dos lagares, pudesse repetir a prova, não obstante uma postura desta altura autorizar os candidatos "de qualquer officio", nestas condições, a repetir o exame passados seis meses ${ }^{19}$. Encerrada a época dos lagares, é provável que as funções dos examinadores desse ano cessassem com ela. Daí a hipótese que aventámos: de os excluídos desta prova só a poderem repetir por alturas da próxima época de laboração dos lagares. $\mathrm{O}$ custo do exame era da ordem dos quarenta réis (vinte para cada um dos examinadores), pagos pelo candidato a mestre lagareiro. E era mediante a apresentação da carta de examinação na Câmara, onde era vista, confirmada e registada num livro destinado ao assento deste tipo de documentos, que o escrivão camarário lhe passava a carta de mestre ${ }^{20}$.

${ }^{17}$ Este estudo foi feito pelo autor para servir de introdução à obra de F.-P. Langhans sobre As corporações dos oficios mecânicos, onde se encontra publicado (vide volume primeiro, pp. XI-LXXIV. A referência supra encontra-se nas pp. XVII-XVIII).

${ }^{18}$ Se alguma dúvida possa subsistir acerca do significado desta expressão, esta passagem Do Regimento dos livreiros de Lisboa de 1572, relativa ao exame dos candidatos a mestres deste ofício, afasta-a definitivamente: "E porque os liuros grandes de Igreia de pelle inteira solfados pelo lombo são muj custosos, e os officiaes que delles se quisesse $[m]$ examinar os não poderião hauer facilmente aas mãos [nos] seus exames, mandão que os examinadores examinem os ditos officiaes que de tal obra examinar se quiserem per pratica, fazendo lhes as perguntas necessarias da maneira que hão de raspar o tal liuro, e solfar pelo lombo, e grudalo, e coselo, e entabolalo, e achando os habiles [...]" (LROM / Virgílio Correia, ob. cit., pp. 103-104). Esta expressão, que sublinhámos, também aparece com o mesmo sentido no Regimento dos confeiteiros (Id. Ib., pp. 207-208).

${ }^{19}$ Vide LROM, Livro segvndo de posturas geraes para os officiaes mecanicos, cap. XII - Que não examinem dahi a seis meses os $\widetilde{q}$ não acharẽ sufficiẽtes (Vergílio Correia, ob. cit., p. 239).

${ }^{20}$ De acordo com o que se passava nos outros ofícios, a carta de examinação, depois de vista e confirmada pela edilidade (vereadores), era registada "no liuro em que as taes cartas se registrão" (LROM, caps XI - Do Regimento dos Sarralheiros, e XL - Do Regimento dos Tanoeiros / Vergílio Correia, ob. cit., pp. 55 e 127). Em Coimbra, os candidatos a um ofício também tinham de submeter-se a esta mesma avaliação, conforme vemos numa postura quinhentista desta cidade: "Toda pesoa, homem ou molher que nesta cydade e termos ouver de poer tenda ou usar de qualquer oficio que seja, nam usara o tall oficio nem pora tenda sem prymeiro ser examynado 
Os mestres lagareiros estranhos à cidade e ao termo de Lisboa, que quisessem trabalhar nos seus lagares, teriam de submeter-se a este exame, independentemente de já o terem feito com aprovação noutras terras, conforme mandava uma postura municipal desta altura ${ }^{21}$.

Mas, para ser mestre, o interessado devia também prestar juramento na Câmara e apresentar fiador (ou fiadores), tal como apresentavam "os outros officiais que recebem do alheio" 22 . O fiador, a apresentar por ele, não poderia, no entanto, ser o dono do lagar, se se tratasse de uma pessoa nobre e poderosa, porque, neste caso, devido à sua condição, não se poderia obrigar a pagar eventuais prejuízos. De acordo com o Regimento dos lagareiros, os fiadores deviam ser "tais per que se bem possa aver aquyllo por que os laguareiros forem obriguados" ${ }^{23}$.

Todo o lagareiro que se aventurasse a desempenhar as funções de mestre sem estar devidamente habilitado, e fosse denunciado à Câmara, seria punido com quinze dias de tronco (cadeia) e 2000 réis de multa, metade para as despesas da cidade e a outra metade para quem o acusasse, conforme era costume ${ }^{24}$.

pollos examynadores e juizes do taall oficio, ordenados e eleytos pollo costume da cidade. E sendo examinados, os taaes juizes lhe pasaram sua certidão per elles asinada em que declarem as cousas pera que a tall pesoa he soficyente e por a tall certidão sera pasado carta em forma aa tall pesoa, feyta polo escripvão da Camara e asinada pollo juiz e vereadores e sellada com o sello da cidade. E sendo a tall carta da maneira que dito he, então podera poer sua tenda e usar de seu oficio e fazendo-ho d'outra maneira pagara mill reis da cadea, a metade pera a cidade e a outra pera quem os acusar" ( $L C, 1$, cap. 153 / J. Pinto Loureiro, ob. cit., pp. 41-42).

${ }^{21}$ Vide LROM, Livro segvndo de posturas geraes para os officiaes mecanicos, cap. XVI - Que os officiaes que forem examinadores [sic] fora desta cidade se tornem nella a examinar (Vergílio Correia, ob. cit., p. 241). É provável que em Coimbra os lagareiros de fora tivessem, também eles, de se submeter a este exame, embora António de Oliveira, no estudo que temos vindo a citar, não preveja tal hipótese (vide pp. 508-510).

${ }^{22}$ Esta mesma exigência se nos depara da parte das autoridades coimbrãs, onde numa postura se obrigava todos os oficiais mecânicos da cidade e termo, entre os quais os lagareiros, a prestar juramento e a dar fiança, " $2{ }^{\circ}$ costume amtiguo", por todo o mês de Janeiro de cada ano, ficando tudo escrito num livro existente na Câmara ( $L C, 1$, Regimento dos lagares d'azeyte, cap. 150 / J. Pinto Loureiro, ob. cit., p. 41).

${ }^{23}$ Reg. ${ }^{o} 1572$, cap. 1 (Ap. Doc., p. 310).

${ }^{24}$ Id., cap. 1. Em Coimbra, em 1554, os candidatos a mestres também tinham de se submeter a um exame; prestar juramento na Câmara e dar fiança. O juramento e a fiança só seriam aceites pelo escrivão da Câmara mediante a apresentação do alvará de examinação. O exame, só por si, não bastava para o desempenho desta função. Sem a prestação do juramento e a apresentação da fiança, os donos dos lagares (ou rendeiros) e mestres que trabalhavam nestas condições arriscavam-se ao pagamento de uma multa de 300 e 500 réis, respectivamente. Ainda em relação aos mestres que não haviam apresentado fiança, caso se verificassem prejuízos, por ele causados ou pelos seus mancebos, era sobre os donos dos lagares (ou rendeiros) que recaía o ónus de indemnizar os donos da azeitona que haviam sido lesados. Por um acórdão posteriormente anexado a este 
O moedor, que este regimento proíbe que seja parente ou amigo do mestre, para se "evitar os furtos que huns a outros comsintem sendo parentes ou dividos" 25 , estava, também ele, obrigado a prestar juramento na Câmara antes de iniciar esta actividade. Como o nome indica, tinha a seu cargo a tarefa da moagem da azeitona, assim como a da sua medição, antes de a lançar na vasa do moinho para aí ser triturada. Embora a azeitona já tivesse sido medida anteriormente aquando do seu entulhamento, o Regimento de 1572 obrigava o moedor a repetir esta operação na presença do mestre, "quoando se houver de moer e saber se lhe fez verdade o acaretador ou o dono da azeytona, se ha mandar medir".

A medição da azeitona, antes de ser moída, era também obrigatória para que o respectivo dono ficasse a conhecer o seu rendimento em azeite (funda). A presença do mestre nesta operação tinha em vista reforçar o testemunho do moedor, no caso de se terem verificado erros na medição anterior: "A quoall [azeytona] medira o dito moedor peramte o laguareiro pera, per seu juramento, serem cridos aserqua do erro da medida da azeytona que se lhe fizer nas tulhas". Sobre ele, devia igualmente recair a tarefa do enchimento das seiras com a massa da azeitona, antes de estas seguirem para as prensas, a fim de lhe ser extraído o azeite e a água de vegetação que ainda continha ${ }^{26}$.

O acarretador, ao qual estava afecta a tarefa do transporte da azeitona - nomeadamente de casa de alguns clientes para o lagar - e, nalguns casos, também a da sua medição, era obrigado a prestar juramento na Câmara, antes de entrar ao serviço do dono (ou rendeiro) de um lagar, como auxiliar do mestre. Também não podia ser parente ou amigo deste oficial, pela mesma razão que apontámos para o moedor ${ }^{27}$.

regimento, o escrivão da Câmara, antes de lhes dar juramento, devia ler-lhes o seu conteúdo e entregar-lhes uma cópia do mesmo, para que eles a tivessem consigo quando trabalhassem no lagares. Quanto à remuneração do mestre (e também a dos mancebos que trabalhavam com ele), que o Regimento dos lagareiros dos lagares de azeite de Lisboa de 1572 não refere, processava-se em Coimbra em dinheiro, ou em dinheiro e azeite. O pagamento exclusivamente em azeite não era permitido ( $L C, 1$, Regimento dos lagares d'azeyte, caps 2, 3, 19 e 38 / J. Pinto Loureiro, ob. cit., pp. 2-4, 8 e 14 . Sobre este mesmo assunto, vide a postura coimbrã que transcrevemos na nota 20$)$.

${ }^{25}$ Reg. ${ }^{o}$ 1572, cap. 4 (Ap. Doc., pp. 310). O Regimento dos lagares d'azeyte de Coimbra de 1554 também proibia os lagareiros de ter parentes a trabalhar consigo nos lagares, a pretexto de que "era gramde emconvenyente pera o proveito do povo e gramde danno das comciemcias dos ditos mestres e mamcebos" ter ao serviço indivíduos nestas condições. O escrivão da Câmara estava igualmente proibido de dar juramento a indivíduos aparentados, caso estes pretendessem trabalhar num mesmo lagar (cap. 35 / J. Pinto Loureiro, ob. cit. pp. 35-36).

\footnotetext{
${ }^{26}$ Reg. $^{o}$ 1572, caps 4, 10, 11 e 14 (Ap. Doc., pp. 310-312).

${ }^{27}$ Id., caps 4, 10 e 11 (Ap. Doc., pp. 310-312).
} 
Ainda em relação a estes dois últimos ofícios, o de moedor e o de acarretador, o Regimento de 1572 impedia que fossem desempenhados por escravos, a pretexto de que implicavam um juramento, juramento esse que eles, pela sua situação face ao direito, não podiam prestar. Podiam, no entanto, trabalhar nos lagares, se fosse essa a vontade dos respectivos donos, mas tão-somente como ajudantes do acarretador ${ }^{28}$.

\section{Normas relativas à medição, ao acondicionamento e à moagem da azeitona}

A medição da azeitona devia ser feita pelo respectivo dono ou por alguém da sua confiança, por ele mandatado, no lagar. No caso de o dono não a querer medir, ou mandar medir, o regimento ordenava que fosse, então, o acarretador a fazê-lo, atendendo ao juramento que este havia prestado na Câmara para o efeito. A medição devia ser feita por uma meia fanga e de rasoira, ou seja, sem cogulo ${ }^{29}$.

Um outro regimento de lagares de azeite desta cidade, sem data, mas decerto posterior ao de 1572, dá-nos algumas indicações preciosas acerca desta medida. Diz-nos que era formada por cinco peças de madeira, "sem pedaço nenhum nem acrescentamento por bacho nem por sima", e com um varão de ferro na sua parte superior, varão esse que lhe servia, decerto, de rasoira. Quanto à sua capacidade, que também refere, diz que era de dois alqueires, sendo, por conseguinte, a fanga de quatro alqueires ${ }^{30}$.

Em todos os lagares de azeite devia haver duas meias fangas, aferidas pelo aferidor da cidade de Lisboa, devendo uma delas estar "comtinuadamente nas tulhas que se acaretarem pera por ella se medir $[a]$ azeytona, quoando se

${ }^{28}$ Reg. $^{o}$ 1572, cap. 14 (Ap. Doc., p. 312). O Regimento dos lagares d'azeyte de Coimbra de 1554 fala em escravos e negros, cuja presença nos lagares, como "mamcebos", proíbe expressamente, bem como o escrivão da Câmara de aceitar o seu juramento (cap. 26 / J. Pinto Loureiro, ob. cit., p. 9).

${ }^{29}$ Reg. $^{o} 1572$, caps 10 e 11 (Ap. Doc., pp. 311-312).

${ }^{30}$ Regimento de lagar de azeite, cap. 4 (Artur Salvado, ob. cit., pp. 50-51). Relativamente a este documento, de que existem duas cópias sem data na Biblioteca Nacional de Lisboa (cx. 28-H, 5, 47, n 27 , segundo indicação do autor), é provável que não se trate de um regimento novo, mas sim de um aditamento ao de 1572. A data avançada para este documento (séc. XVII) e a respectiva fundamentação foi analisada por Luís Ferrand de Almeida em recensão crítica à obra de Artur Salvado (Revista Portuguesa de História, tomo IX, Coimbra, Fac. Letras, Instituto de Estudos Históricos Dr. António de Vasconcelos, 1960, p. 313). 
houver de moer, e saber se lhe fez verdade o acaretador ou ho dono da azeytona, se ha mandar medir" 31 . É provável que a outra estivesse sempre na posse do acarretador, para com ela se medir a azeitona dos fregueses, aquando da sua ida às casas destes, a buscá-la para o lagar. Esta mesma fonte proibia que se calcasse a azeitona antes de a rasoirar: a "medida de rasoura sera avellada e não calcada" 32 .

A azeitona, depois de medida, seguia para as tulhas do lagar, onde ficava a aguardar a sua vez para ser moída, e onde aquecia. O seu acondicionamento nos lagares também foi objecto da atenção do legislador. Conforme se dispõe no capítulo 9, em todos os lagares de Lisboa e termo deviam existir tulhas "bem repartydas", e com capacidade para armazenar cinquenta moeduras de azeitona, ou seja, a quantidade que cada um deles podia despachar num mês ${ }^{33}$ :

Uma moedura de azeitona era a quantidade deste fruto que era necessário moer para cada enseiramento. De acordo com o regimento sem data a que aludimos na página anterior, cada moedura de azeitona, nos lagares de Lisboa e termo, não devia levar mais de trinta e cinco meias-fangas, ou seja, setenta alqueires, que era, na opinião do legislador, a "medida proporcionada para cada moedura" 34 . Em Coimbra, a "moedura inteira" era de 36 alqueires de azeitona, e no passado havia sido de $40^{35}$. Se o alqueire de Coimbra tinha a capacidade de 13,161 litros e o de Lisboa a de 13,8 litros, feitas as

${ }^{31}$ Reg. ${ }^{\circ}$ 1572, cap. 11 (Ap. Doc., p. 312). Em Coimbra, a medição da azeitona era obrigatoriamente feita pela fanga, que aqui era de dois alqueires, com "rasoura feyta e acerttada e marcada polos padrões e marca desta cydade" ( $L C, 1$, Regimento dos lagares d'azeyte, caps 5 e 8 / J. Pinto Loureiro, ob. cit., pp. 4-5).

${ }^{32}$ Reg. ${ }^{o}$ 1572, cap. 11 (Ap. Doc., p. 312).

33 A acumulação de grandes quantidades de azeitona nos lagares dava origem, por vezes, a reclamações do povo, por ela se estragar, em virtude de não ser moída no devido tempo. Em Coimbra, por volta de 1554, queixavam-se os donos da azeitona, dizendo que "os senhoryos dos lagares ou aquelles que os tem aremdados nom fazem senam recolher gramde soma d'azeite aos lagares e, despois, nom podem fazer os azeites ao tempo que se deve fazer, e aimda muyttas vezes lhes fallece a aguoa. De maneira que os donos dos azeites recebiam perda em seus azeites e o pior que hera que se os queriam ir fazer a outros lagares lh'os nam queriam deyxar tirar [...] foi provydo e detriminado que os donnos dos azeites posão, cada e quamdo quiserem tirar e levar seus azeites, domde quer que os tyverem empilhados em quaesquer lagares, pera omde os quiserem ir fazer, [...] “ (LC, 1, Regimento dos lagares d'azeyte, cap. 28 / J. Pinto Loureiro, ob. cit., p. 10).

${ }^{34}$ Regimento de lagar de azeite, caps 4 e 8 (Artur Salvado, ob. cit., pp. 50 e 52).

${ }^{35}$ LC, 1, Regimento dos lagares d'azeyte, caps 9 e 27 (J. Pinto Loureiro, ob. cit., pp. 5 e 9-10). Nos lugares onde não havia água em abastança para movimentar as mós, a moedura de azeitona acabaria por baixar ainda mais, fixando-se nos 30 alqueires (vide António de Oliveira, ob. cit., pp. 504-505). 
contas, verificamos que a moedura de azeitona nesta cidade levava 966 litros, enquanto a de Coimbra tão-somente 473,8 litros. Isto significa que, enquanto em Coimbra, num lagar de duas varas, se despachava 4 moeduras de azeitona/dia (1 895 litros $)^{36}$, num de Lisboa, com as mesmas características, tão-somente duas (1 932 litros). Mas estas duas moeduras de azeitona, em circuntâncias normais, ultrapassavam em 37 litros a quantidade de azeitona moída diariamente nos lagares do Mondego. Atendendo à capacidade da moedura de Lisboa e ao número de seiras autorizado para cada prensa $(5 \text { ou } 6)^{37}$, é de supor que os lagareiros desta cidade repartissem a massa da azeitona de cada moedura por duas prensas, aonde estaria sob pressão à volta de doze horas, para se lhe extrair o azeite e a água de vegetação que continha. Pelas nossas contas, cada uma das seiras devia levar à volta dos 65 quilos de massa.

Lembramos que, de acordo com o regimento, nenhuma azeitona podia ser lançada na vasa para ser triturada sem ser novamente medida. Esta imposição era justificada pela necessidade de se verificar se teria havido ou não erro na sua medição e conhecer o respectivo rendimento em azeite, conforme referimos.

Quanto à sua entrada em laboração, para se evitar que a dos poderosos ou a dos amigos pudesse ter prioridade sobre a demais, o Regimento dos lagareiros dos lagares de azeite ordenava aos mestres que respeitassem a ordem da sua entrada nos lagares. As cedências ou trocas de vez eram permitidas, desde que os donos da azeitona, que primeiramente havia dado entrada nos lagares, as autorizassem ${ }^{38}$.

${ }^{36}$ Segundo o seu regimento de 1554 , nenhum mestre podia fazer "mais moeduras amtre noytte e dia que quatro no laguar que nam tever mais que duas varas e sendo azeite bom de lavrar. E asi [se] tever tres varas, poderaa fazer attee cimquo moeduras, semdo o azeyte bom, amtre noyte e dia. E se o azeyte for taal que mereça fazer-se dele menos moeduras asi o faraa, [...]" (LC, 1, Regimento dos lagares d'azeyte, cap. 29 / J. Pinto Loureiro, ob cit., p. 10).

${ }^{37}$ Sobre este recipiente, vide infra, pp. 279-281.

${ }^{38}$ Nos lagares de Coimbra, também se respeitava a vez, que era marcada pelo mestre, não devendo os donos dos lagares (ou rendeiros) se intrometer neste assunto: "somente [o dono] podera fazer o seu proprio azeite quamdo quiser, sem meter outro allgum, porquamto ao dito mestre pertence o taal carguo, por ter juramento e estaar comtinuadamente no lagar, e saber qual azeitona tem mays necesydade de se fazer". O mestre não podia, no entanto, prometer vez a mais de "tres pesoas, a saber, que vaa hũa a pola outra e amte de acabar o deradeyro poderão prometer a outros tres pola dita maneira, em taal guissa que numqua mais sejam que tres pesoas as que tyverem vez pelle mestre promettida" ( $L C, 1$, Regimento dos lagares d'azeyte, caps $14 \mathrm{e}$ 16 / J. Pinto Loureiro, ob cit., pp. 6 e 7). 


\section{Normas relativas ao acondicionamento do azeite e ao seu desvio nos lagares}

No que diz respeito ao azeite, o Regimento de 1572 impunha algumas normas, uma delas relativa ao acondicionamento do azeite cru. No capítulo 13, exigia-se aos donos dos lagares que tivessem nas suas instalações potes em número suficiente para "aguasalhar huum quoarto d'azeite cru, que rezoadamente se pode fazer entre dia e noite" 39 . Se o quarto tinha a capacidade de 13 almudes (218, 4 litros), conforme informa o Regimento dos Tanoeiros de Lisboa desta mesma data $(1572)^{40}$, e o pote 6 canadas ( 8,4 litros), isto significa que em todos os lagares devia haver, no mínimo, 26 potes $^{41}$. É provável que este vasilhame estivesse disposto em redor da sala dos engenhos para não estorvar a azáfama dos lagareiros e evitar que se quebrassem, à semelhança do que vemos no desenho de um lagar de vinho do século XIX, que apresentamos na p. 321 (fig. 8).

Por azeite cru, entendemos tratar-se de um azeite que não fora submetido, nem à acção do calor da fornalha (nos lagares de sertã) ${ }^{42}$, nem das águas ferventes (nos lagares de água ou de calda) ${ }^{43}$, para se lhe tirar o sabor herbáceo, característico dos azeites novos, e torná-lo mais fluido e limpo das suas impurezas.

O número de moeduras por dia andava à volta de duas, conforme se conclui do capítulo 9 do Regimento dos lagareiros dos lagares de azeite, onde se diz que "em todo [ho] laguar d'azeite avera tulhas bem repartydas, em que se bem posão recolher cimquoenta moeduras de azeytona que se podem fazer em huum mês $[\ldots]]^{\prime 44}$. Se descontarmos os domingos, em que provavelmente não se trabalharia por ser o dia consagrado ao descanso e à oração, a média obtida

${ }^{39}$ Reg. $^{\circ} 1572$, cap. 13 (Ap. Doc., p. 312).

${ }^{40}$ LROM, cap. XL - Do Regimento dos Tanoeiros / Vergílio Correia, ob. cit., p. 128.

${ }^{41}$ No regimento sem data, publicado por Artur Salvado, exigia-se aos lagareiros que tivessem nos seus lagares "ao menos doze cântaros, e estes não serão afilados porquanto servem sòmente dos despejos dos azeites das correntes, porém, levarão de dois potes para cima cada um" (Id., ob. cit., p. 52). Estes doze cântaros, destinados aos "despejos dos azeites das correntes", ou seja, à recolha do azeite que escorria das prensas juntamente com alguma água de vegetação da azeitona, deviam ter uma capacidade muito próxima do volume dos 26 potes acima referidos (218, 4 litros). A mudança dos potes para cântaros, entretanto verificada, deve-se ter ficado a dever à pouca capacidade daqueles recipientes e à necessidade de reduzir o espaço que ocupavam nos lagares.

${ }^{42}$ A propósito da sertã dos lagares desta tipologia, vide o que dizemos nas pp. 295-296 e o desenho que apresentamos na p. 318 (fig. 1).

${ }^{43}$ Sobre este tipo de lagares, vide infra, pp. 297-299.

${ }^{44}$ Ap. Doc., p. 311. 
é de duas moeduras por dia, para um lagar de duas varas, o que daria à volta de um quarto de azeite.

Se o quarto tinha a capacidade de 13 almudes e o almude doze canadas, ou seja, 16, 8 litros (sendo a canada de 1,4 litros), isto significa que, diariamente, se recolhia uma média de 218, 4 litros de azeite, o que corresponde a um rendimento da ordem dos $11,3 \%$ da azeitona moída, estimada em 1932 litros $^{45}$. Embora esta percentagem seja baixa, comparativamente aos valores actuais, não deixa, contudo, de ser uma boa percentagem para a época, atendendo ao tipo prensas e aos processos de extracção do azeite destes tempos recuados. No início do século XX (1903), em algumas destas oficinas, ainda se não ia além, ou muito além, dos 9 e $10 \%{ }^{46}$. Em relação ao rendimento da azeitona entulhada da região de Lisboa, nesta altura, podemos acrescentar que, para se obter um litro de azeite, eram necessários à volta de nove litros de azeitona ( 8,85 litros).

Como nos lagares de sertã - para cuja tipologia as adições ao Regimento dos lagareiros dos lagares de azeite de Lisboa (1572) parecem apontar - a cozedura do azeite, de que vínhamos a falar, parece andar atrasada um dia, relativamente à moagem da azeitona e à prensagem da respectiva massa, daí a necessidade de haver potes em número suficiente nestas instalações, para recolher e "aguasalhar" o azeite saído das prensas até este dar entrada nas sertãs, para aí ser cozido. Com esta disposição, procurava-se, decerto, evitar que os engenhos, por falta de potes para a recolha do azeite cru, estivessem parados, sobretudo em anos de boas colheitas, em que era necessário dar despacho às várias carradas de azeitona entulhada nos lagares e em casa dos produtores.

A Câmara de Lisboa preocupou-se, igualmente, com o problema do desvio de azeite nos lagares da cidade e termo. Estamos perante um produto caro, muito procurado para a alimentação, iluminação e para a indústria da saboaria ${ }^{47}$ (e não só) e, por conseguinte, alvo da cobiça alheia, a começar nos lagares onde era extraído. Para minimizar este problema, que lesava os donos da azeitona e contribuía para uma má imagem desta indústria, introduziram-se no

${ }^{45}$ Em relação à quantidade de azeitona moída diariamente nos lagares de Lisboa, vide supra, pp. 275-276.

${ }^{46}$ Cfr. João da Motta Prego, Olivea e lagares: Andaluzia, Catalunha, Nice Toscana, Bari, Portugal, Lisboa, Typ. Da Livraria Ferin, 1902 (?), p. 341.

${ }^{47}$ Nos inícios do ano de 1576, encontramos como donatários das saboarias da cidade de Lisboa os herdeiros de D. Jerónimo de Castro (vide Eduardo Freire de Oliveira, ob. cit., $1^{\text {a }}$ Parte, t. I, p. 597). Conforme informa Motta Prego, o azeite é constituído, fundamentalmente, por três substâncias: a oleina (a mais fina e fluida), a estearina e a palmitina (as mais crassas). No início do século passado (e provavelmente também na segunda metade do século XVI), no caso dos azeites impróprios para consumo humano, a oleína era utilizada na iluminação e as outras duas substâncias na indústria da saboaria (ob. cit., p. 300). 
regulamento de 1572 algumas disposições, tendentes a evitar que tais roubos se verificassem no interior destas instalações. É o caso das disposições relativas à medição da azeitona, de que já falámos no item anterior; ao número de seiras da coluna dos tabuleiros (alguergues) das prensas e à dimensão das mesmas; às medidas destinadas ao azeite, que deviam existir em todos os lagares de Lisboa e termo, e relativas à moagem da azeitona dos lagareiros nos lagares onde estes trabalhavam.

No que diz respeito à pilha de seiras dos tabuleiros, os lagareiros não podiam colocar nela mais de seis com "baguaça", ou seja, com massa de azeitona que já havia sido submetida à acção da prensa e, consequentemente, já perdido boa parte da água de vegetação e do azeite que continha, e de cinco com massa "fresqua" (fresca) ${ }^{48}$. Neste caso, trata-se da massa da azeitona que ainda não havia sido submetida a nenhum aperto na prensa.

No tocante às seiras dos lagares de azeite, temos uma descrição delas do tempo do P. ${ }^{\text {e }}$ Rafael Bluteau. Diz o autor que "saõ humas rodas de esparto, cerradas por baixo, com as bocas em cima; nellas se bota a maça da azeitona $\&$ se espreme o azeite, \& se sustentaõ abertas para se lhe botar a maça com uns paosinhos de hum palmo a que se chamaõ Frades, que se lhes tiraõ depois de estarem cheas; \& se lhe poem por cima Capachos para a dita maça não sahir" ${ }^{\text {"49 }}$. Este modelo de seiras devia ser semelhante ao usado nos lagares de Lisboa por volta de 1572. A única diferença, que poderia eventualmente existir, residia no uso de capachos ou discos de esparto, que eram colocados, no tempo de Bluteau, sobre as respectivas bocas "para a dita maça não sahir". Segundo Motta Prego, a finalidade destes discos, que se continuavam a usar no seu tempo, era outra, ou seja, a de facilitar "a derivação (saída ?) do azeite" ${ }^{50}$. No tempo do regimento lionino, além do uso eventual destes diafragmas, também se costumava colocar cintas de esparto nas seiras para que estas, sob a pressão da vara, não rebentassem ${ }^{51}$.

Ainda em relação às seiras, o Regimento dos lagareiros dos lagares de azeite não se limitou a estabelecer o número máximo de recipientes que podiam ser colocados nos tabuleiros das prensas. Vai mais longe, fixando o diâmetro que as

${ }^{48}$ Reg. $^{\circ}$ 1572, cap. 15 (Ap. Doc., pp. 312-313).

${ }^{49}$ Id., Vocabulario portuguez e latino, aulico, [...], vol. I, Coimbra, No Collegio das Artes da Companhia de Jesu, Anno de 1712, s. v. "Seiras". Sobre esta alfaia, vide p. 320 (fig. 5).

${ }^{50}$ Id., ob. cit., p. 98. Sobre este tipo de apresto, vide o modelo que apresentamos na p. 320 (fig. 6), cuja proveniência e antiguidade não sabemos, todavia, precisar.

${ }^{51}$ Vide LROM, cap. XLV - Do Regimento dos Esparteiros (Vergílio Correia, ob. cit., p. 150). 
mesmas deveriam ter: "quoatro pallmos e tres dedos", ou seja, à volta de $0,96 \mathrm{~m}^{52}$. O controlo desta medida era feito em casa dos esparteiros pelos juízes deste ofício, antes de as seiras serem levadas para os lagares. Esta verificação, em casa dos esparteiros, justificava-se pelo facto de estes mesteirais estarem proibidos, pelo seu regimento desta mesma altura, de fazer "seiras de azeite de cinco palmos, ou de outra qualquer medida que não seja de vitola da cidade, saluo avendo licença da Camara para isso" ${ }^{53}$. Mais tarde (séc. XVII ?), a largura das seiras destinadas à azeitona fresca passou a estar condicionada à largura dos alguergues, não podendo sair fora deles, enquanto o diâmetro daquelas que estavam reservadas para o bagaço podia variar entre os quatro e meio e os cinco palmos, ou seja, entre um metro e $1,13 \mathrm{~m}^{54}$.

Um número excessivo de seiras na coluna do enseiradouro, ou o aumento do seu diâmetro, com vista a levarem uma maior quantidade de massa de azeitona, diminuía a eficácia das prensas e, consequentemente, a percentagem do azeite dela extraído, que era, já de si, reduzida. Segundo Motta Prego, "uma prensa de vara, capaz de dar a pressão de 1 k, 440 por $\mathrm{cm}^{2}$ se o diametro do seu enceiradouro fôr de $0^{\mathrm{m}}, 75$ só poderá fornecer a pressão de $0^{\mathrm{k}}, 789$ alargando-se o seu enceiradouro ao diametro de $1^{\mathrm{m}}$; e dará apenas $0^{\mathrm{k}}, 548$ se o diametro do enceiradouro fôr de $1^{\mathrm{m}}, 20$ " 55 . Na opinião de alguns antigos oleicultores, as prensas de varas mais eficazes, depois de actuarem 12 horas, ainda deixavam perto de $50 \%$ de óleo nas massas. E daí a necessidade de as submeter, depois

${ }^{52}$ As seiras dos lagares de azeite de Coimbra eram um pouco maiores: deviam ter, no mínimo, "quatro palmos e meio e d'y pera cima e nam pera fumdo", ou seja, à volta de um metro (LC, 1, Regimento dos lagares d'azeyte, cap. 11-a / J. Pinto Loureiro, ob cit., p. 6).

${ }^{53}$ LROM, cap. XLV - Do Regimento dos Esparteiros (Vergílio Correia, ob. cit., pp. 150-151). João António Dalla-Bella, na segunda metade do século XVIII, ao tratar do Modo de fazer o Azeite em Portugal, e seus defeitos, diz o seguinte acerca do seu fabrico, estado de conservação e uso nos lagares de azeite do seu tempo: "Estas [seiras] saõ feitas de esparto muito bem fabricadas, mas taõ mal conservadas, que posto que se lavem, fedem ainda ao ranço; [...] e usaõ dellas indiferentemente seja a massa de azeitonas boas e bem conservadas, ou de azeitonas podres e que cheiraõ mal" (Id., Memórias e observações sobre o modo de aperfeiçoar a manufactura do azeite de oliveira em Portugal, remetidas à Academia Real das Ciências pelo seu sócio Dr. [...], Lisboa, 1784, p. 50). O que se verificava nesta altura não devia divergir muito, relativamente a tempos anteriores, conforme se conclui do regimento de Coimbra de 1554, onde se ameaça com a pena de 100 réis todo o mestre que fosse apanhado a "lavrar" com seiras não consideradas "sãas e proveitosas para o azeite" (LC, 1, Regimento dos lagares d'azeyte, cap. 11-a / J. Pinto Loureiro, ob cit., p. 6).

${ }^{54}$ Regimento de lagar de azeite de Lisboa (s. d.), cap. 11 (Artur Salvado, ob cit., p. 54).

55 João Motta Prego, ob.cit., p. 340. 
de remexidas e escaldadas com água fervente, a mais uma ou duas pressões, para se obter mais algum azeite ${ }^{56}$.

No espírito do legislador do capítulo 15 do Regimento de 1572 que temos vindo a analisar, pode ter estado o desejo de evitar que os donos (ou os rendeiros) dos lagares de azeite, através do acréscimo do número de seiras da coluna do enseiradouro, ou do seu diâmetro, aumentassem a percentagem de óleo retido nos bagaços, tendo em vista o seu posterior aproveitamento, no tocante à parte dos resíduos que lhes competia ${ }^{57}$. Uma outra motivação, que os podia levar a adoptar um ou outro dos expedientes, prejudiciais para os donos da azeitona, prendia-se com a necessidade de aumentarem a capacidade de laboração das suas oficinas, sobretudo nos anos de boas colheitas, em que era necessário dar despacho à azeitona acumulada.

A mesma preocupação, no sentido de se evitar o desvio deste precioso óleo, parece ter estado, igualmente, na origem de uma outra disposição, esta respeitante às medidas a ele destinadas. Nela se determinava que em todos os lagares de azeite existisse um conjunto de medidas, que ia do cântaro (16,8 ou mais

${ }^{56}$ À deficiência das prensas, juntava-se, por vezes, o desleixo ou a má fé dos lagareiros. No Regimento dos lagares d'azeyte de Coimbra de 1554, dizia-se que "huum dos gramdes males e gramde perda que o povo recebe no fazer de seus azeites asi he pollos mestres dos dittos lagares nom deixarem moer $[a]$ azeitonna segumdo deve ser e escousar a masa segumdo merece, e muytas vezes se tem visto e achado ser a baganha tão mal moyda e escousada que hee cousa vergonhosa e dinna de bom castigo e [...]" (Id., cap. 30 / J. Pinto Loureiro, ob cit., p. 11).

${ }^{57} \mathrm{O}$ bagaço era utilizado, nesta altura, na alimentação de alguns animais e também como combustível nas fornalhas dos lagares de azeite. A elevada percentagem de óleo que continha, depois de a massa da azeitona ter sido submetida duas ou mais vezes à acção da prensa, levou a fazenda real, no tempo de Filipe III, a adoptar o processo da repisa do bagaço - que a Espanha, muito recentemente, havia adoptado - para extrair esse óleo em benefício próprio. A carta de 15 de Novembro de 1630, que criou o Benefício do bagaço da azeitona, tem, em anexo, um conjunto de instruções sobre o modo como devia ser feita esta repisa, bem como a planta de um lagar adaptado para este efeito (para mais informações sobre este encargo, vide António de Oliveira, "Para a história da oposição ao beneficio do bagaço da azeitona" em Revista Portuguesa de História, tomo XXI, Coimbra, Faculdade de Letras, Instituto de História Económica e Social, 1984, pp. 177-198; F.-P. Langhans, Apontamentos para a história do azeite em Portugal, pp. 110-114, e Esteves Pereira e Guilherme Rodrigues, Portugal. Diccionario historico, chorographico, biographico, heraldico, numismatico e artistico, vol. V, Lisboa, João Romano Torres \& C. ${ }^{\mathrm{a}}$ Editores, 1911, s. v., "olivicultura”). É provável que os donos (ou os rendeiros) dos lagares, por volta de meados do século XVI, já procurassem extrair o azeite dos bagaços que ficavam para si, embora por um processo mais simples, que não devia ir além da sua lavagem com água fervente, para retirarem o óleo que sobrenadava a mistura. 
litros $)^{58}$ ao meio quartilho $(0,1751)$, passando pelo alqueire $(8,41)^{59}$, canada $(1,41)^{60}$, meia canada $(0,71)$ e quartilho $(0,351)$, as quais, para poderem ser usadas e merecer a confiança dos fregueses, deviam estar aferidas pelo aferidor da cidade. A falta de qualquer uma delas nas instalações era punida com a multa de 2000 réis, revertendo metade desta quantia para as obras da cidade e a outra metade para a pessoa que havia denunciado a sua inexistência. Era sobre o dono do lagar que recaía a obrigação de apetrechar as suas instalações com as medidas necessárias para a medição da azeitona e do azeite e, consequentemente, também as multas referentes às faltas detectadas. Quanto à pena a aplicar pelo uso de medidas não aferidas, nada se diz, mas é provável que estas infracções, a acontecerem, fossem punidas com multas de igual valor ${ }^{61}$.

Pelo mesmo motivo da disposição anterior, se proibiu os mestres e os seus auxiliares de moer a sua azeitona nos lagares onde trabalhavam. Com esta medida, procurava-se impedir que estes fossem tentados a aumentar a quantidade da sua azeitona, ou a do respectivo azeite, à custa da azeitona, ou do azeite, dos fregueses. ${ }^{62} \mathrm{E}$ uma vez que não podiam moer a sua azeitona nos lagares onde trabalhavam, também não podiam, por razões óbvias, vender azeite neles, nem receber dinheiro para esse fim. Somente os donos da azeitona ficaram autorizados a fazê-10 ${ }^{63}$.

Foi, certamente, a pensar na prática destes abusos e nas indemnizações a pagar às respectivas vítimas em caso de reclamação, que se passou a exigir aos mestres, antes de iniciarem esta actividade, a apresentação de fiadores, e que

${ }^{58}$ Considerámos o cântaro (ou almude) como tendo a capacidade de doze canadas. De acordo com um regimento posterior (ou aditamento ao de 1572) já por nós referenciado, os cântaros não eram "afilados" (aferidos), porquanto serviam tão-somente para os despejos do azeite "das correntes". Cada um deles devia, no entanto, levar para cima de dois potes, ou seja, no mínimo, os 16,8 litros acima referenciados (Vide Artur Salvado, ob. cit. p. 52).

${ }^{59} \mathrm{O}$ alqueire de azeite foi considerado aqui como tendo seis canadas.

${ }^{60}$ A canada tem quatro quartilhos.

${ }^{61}$ Reg. ${ }^{\circ}$ 1572, cap. 12 (Ap. Doc., p. 312). Relativamente aos lagares de Coimbra, o seu Regimento de 1554 fala do alqueire, da "meya", da "pimta", da "somicha", da "meya-somicha", e também num funil de cobre para transvasar o azeite. As medidas podiam ser de barro ou de cobre, devendo todas elas ser "feytas e acertadas e marcadas polos padrões e marcas desta cydade", e não ter nenhuma "quebradura". Os donos dos lagares (ou os rendeiros), onde faltasse alguma destas medidas (ou a fanga) ou existisse medidas rachadas, seriam punidos com uma multa de cem réis e os mestres, que delas se servissem, com outra de igual valor. Sobre o mestre recaía a responsabilidade da sua guarda e conservação. Logo, se alguma delas desaparecesse, ou se quebrasse, devia providenciar a sua reposição, caso contrário, sujeitar-se-ia ao pagamento de uma multa de 100 réis (LC, 1, Regimento dos lagares d'azeyte, caps 6 e 7 / J. Pinto Loureiro, ob cit., p. 4).

${ }^{62}$ Reg. ${ }^{\circ} 1572$, cap. 7 (Ap. Doc., p. 311).

${ }^{63}$ Id., cap. 5 (Ap. Doc., p. 310). 
estes fiadores fossem pessoas "tais per que se bem possa aver aquyllo por que os laguareiros forem obriguados" $"$. Caso os mestres não pudessem indemnizá-las dos prejuízos por eles causados, era sobre os seus fiadores que recaía esse ónus. O mestre era o único lagareiro a quem o Regimento de 1572 exigia a apresentação de fiadores, precisamente porque era sobre ele que recaía a responsabilidade, quer da moagem da azeitona e da extracção do azeite, quer da guarda de ambos os produtos dentro do lagar. Por esse motivo, não podia dormir "noite allgũa fora delle", devido aos "roubos que se fazem e periguos que em sua absencia podem acomtecer" ${ }^{\prime \prime}$.

\section{Normas relativas à manutenção da moral e da disciplina nos lagares}

A necessidade de manter a moral e a disciplina nos lagares de azeite levou à inclusão, neste regimento, de dois artigos, um deles sobre a presença de mulheres e de pessoas estranhas nos lagares e o outro, relativo à confecção de alimentos à boca das suas fornalhas. No que diz respeito ao primeiro, nenhum lagareiro, durante o período da safra, podia consentir a presença de mulheres nas suas instalações, salvo as donas da azeitona, ou as compradoras de azeite, quando estas, acompanhadas dos respectivos donos, o fossem levantar ${ }^{66}$. Nem elas nem nenhuma outra pessoa estranha ao serviço dos lagares podiam dormir neles de noite, nem mesmo mediante autorização dos respectivos proprietários. E no caso de algum deles pressionar o mestre no sentido de conceder essa autorização, este devia comunicar o facto à Câmara de Lisboa, "pera se fazer o que for justiça"67.

${ }^{64}$ Id., cap. 1 (Ap. Doc., p. 310).

${ }^{65} I d$., cap. 3 (Ap. Doc., p. 310). Nos lagares de Coimbra, foi-se um pouco mais longe nas medidas tomadas para se evitar desvios de azeite (ou de azeitona), proibindo-se, inclusivamente, que nestas instalações existisse mais de que uma serventia: "Acordamos [...] que nenhuum laguar d'azeyte tenha mais de hũa soo servemtia, e os que mays servemtias teverem as taparam amtes que se deitem os laguares a moer [...]" Mais tarde e por mão diferente, foi acrescentado a este capítulo que "esto se entemderaa tendo as taais serventias pera a casa do senhorio ou remdeiro, e esa somente se tapara sob a dita penna" (LC, 1, Regimento dos lagares d'azeyte, cap. 36 / J. Pinto Loureiro, ob cit., p. 14).

${ }^{66}$ Reg. ${ }^{\circ}$ 1572, cap. 6 (Ap. Doc., p. 311). No Regimento dos lagares d'azeyte de Coimbra de 1554 apenas se faz alusão às mulheres dos mestres e mancebos, proibindo-as de irem ter com eles durante o período de laboração dos lagares (cap. 18 / J. Pinto Loureiro, ob cit., p. 8).

${ }^{67}$ Em Coimbra, também se proibia o mestre de dar dormida e agasalho a pessoas estranhas no lagar onde trabalhava (Id., cap. 20 / J. Pinto Loureiro, ob cit., p. 8). 
Quanto à confecção de alimentos à boca da fornalha, apenas o pessoal afecto ao lagar dispunha de autorização para fazê-lo, mas tão-somente quando eles se destinassem à sua própria alimentação. A presença de estranhos nestas instalações, incluindo a de mulheres, para este ou outros fins, não era permitida, salvo nos casos previstos no regimento, de que acima falámos. Esta proibição era, igualmente, extensiva às tibornas, que este corpo normativo apenas autorizava aos donos do azeite, e tão-somente quando estas fossem "pera sy e pera os officiais do laguar". Também neste caso, se algum dono de lagar tentasse violar o que estava estabelecido, o respectivo mestre devia comunicar à Câmara a ocorrência, para que esta agisse contra ele de acordo com a justiça ${ }^{68}$.

A propósito das tibornas, dizem-nos Tude Martins de Sousa e Francisco Vieira Rasquilho, na monografia sobre a povoação da Amieira (conc. Nisa) de que são autores, que "no tempo dos antigos lagares de vara era costume, por vezes, fazer-se nêles o que se chamava uma tiborna (pão quente embebido em azeite novo), o que constituía, afinal, um pretexto para uma ceia alegre. O dono da azeitona que se moía, para provar o seu azeite, levava um ou mais pãis de trigo, moles, que se embebiam bem de azeite, comendo-os depois com alguns amigos, convidados, e os lagareiros. Outras vezes era o pão partido em fatias delgadas e estas fritas em azeite, sendo noutras o pão torrado e depois regado fartamente com azeite. Mais modernamente era tudo isto acrescido com bacalhau cozido ou assado e hortaliça e em tôdas as circunstâncias tudo acompanhado de vinho, nesta altura já da colheita do próprio ano" ${ }^{69}$.

Tudo o que pudesse afectar a moral e a disciplina dentro dos lagares, e desviar os respectivos lagareiros das suas tarefas, foi pensado e proibido por este regimento.

${ }^{68}$ Id., cap. 8 (Ap. Doc., p. 311). Nos lagares de Coimbra, apenas os donos do azeite, mancebos e servidores destes, bem como o pessoal dos lagares, estavam autorizados a fazer tibornas nas suas fornalhas (LC, 1, Regimento dos lagares d'azeyte, cap. 24 / J. Pinto Loureiro, ob cit., p. 9).

${ }^{69}$ Id., Amieira do antigo priorado do Crato, edição fac-simile, Lisboa, Imprensa Nacional-Casa da Moeda, 1982, p. 268, nota 1. Este texto já foi aproveitado, em igual contexto, por F.-P Langhans, "Apontamentos para a história do azeite em Portugal”, p. 73. 


\section{Normas relativas à fiscalização dos lagares e penas aplicadas aos que violassem o disposto no seu regimento}

A actividade dos lagareiros, bem como a moral e a disciplina nos lagares, estavam sob o controlo da Câmara de Lisboa que, para efeito de inspecção, fazia deslocar até eles os seus almotacés das execuções, por vezes acompanhados dos examinadores dos candidatos a mestres desse ano. É provável que cada uma destas comissões fosse composta por um dos referidos almotacés e pelos dois examinadores, conforme se conclui do seguinte passo do seu regimento: "E os ditos examinadores serão obryguados de yrem com cada huum dos allmotacees das execuçoes, todas as vezes que requerydos forem, a visitar os laguares desta cidade e seu termo e verem a obra que se nelles faz [...]" ${ }^{\prime 70}$.

Emrelação aos almotacés das execuções, diz F.-P.Langhans que "estes magistrados eram, ao mesmo tempo, juízes das transgressões e fiscais. Competia-lhes zelarem pelo cumprimento das posturas e regimentos e julgar as infracções praticadas. O seu tribunal denominava-se a Casinha - assim dizia-se: a Casinha da Ribeira. Nas suas voltas pela cidade e pelo termo, ao procederem às visitas de inspecção faziam-se acompanhar, consoante as diligências a efectuar, pelos juízes ou pelos examinadores dos ofícios para que estes, com a sua competência técnica, os auxiliassem. Quando encontravam qualquer falta não só obrigavam o infractor a pagar indemnização por perdas e danos ao prejudicado, como aplicavam as penas prescritas nos regimentos e nas posturas" 71

No que diz respeito aos examinadores, tendo estes sido escolhidos pela Câmara de entre os oficiais lagareiros, compreende-se a necessidade da sua presença nestas comissões, para verificação das questões relacionadas com a prática deste ofício, que os almotacés das execuções decerto não dominavam. No caso de detectarem algumas irregularidades ou de se confirmarem anteriores denúncias à Câmara, os almotacés deviam obrigar os lagareiros a pagar aos donos da azeitona os prejuízos por eles causados e aplicar-lhes as respectivas penas.

A remuneração dos examinadores, pelo seu trabalho e dias despendidos nestas acções de fiscalização, era paga pelo rendeiro do termo, por ordem dos almotacés das execuções, e de acordo com os critérios de justiça destes oficiais camarários $^{72}$.

\footnotetext{
${ }^{70}$ Reg. ${ }^{\circ}$ 1572, cap. 2 (Ap. Doc., p. 310).

${ }^{71}$ Ob. cit., p. 99.

${ }^{72}$ Reg. ${ }^{\circ} 1572$, cap. 2 (Ap. Doc., p. 310).
} 
Para que as leis se cumpram, não basta legislar! É também necessário estabelecer penas para se evitar que as violem, ou punir os seus transgressores. Daí que o legislador deste regulamento tenha, no geral, feito acompanhar cada uma das suas normas da respectiva punição, em caso de incumprimento.

As penas previstas podiam envolver a privação da liberdade e/ou o pagamento de uma determinada quantia em dinheiro. Quanto ao número de dias de cadeia (tronco), apenas se refere um caso, que diz respeito àqueles obreiros que, porventura, se atrevessem a exercer o ofício de lagareiro sem estarem devidamente habilitados para o efeito. Para estarem aptos para o exercício deste mester, recorde-se, precisavam de possuir carta de mestre, o que implicava submeter-se a um exame; prestar juramento na Câmara e apresentar fiadores credíveis $^{73}$. Caso contrário, se fossem denunciados, seriam punidos com quinze dias de tronco e com a multa de 2000 réis $^{74}$.

Segundo Eduardo Freire de Oliveira que passamos a citar, o tronco "era uma prisão puramente municipal, especie de casa de detenção, differente da cadeia do concelho (que tambem havia a cadeia da côrte). Ali se encarceravam os que tinham de soffrer esse castigo por sentença dos almotacés, e se expiavam os pequenos delitos: egualmente servia de calabouço, onde se detinham em custodia os presos, emquanto os magistrados d'elles não decidiam; na cadeia cumpriam-se as penas por crimes de maior gravidade, e as ordenadas pelas justiças d'el rei. O tronco foi expressamente estabelecido pela camara para os presos da almotaçaria; e é de presumir que the proviesse aquelle nome de n'elle existirem dos taes cepos com olhaes, para prenderem os pés e o pescoço. Mais tarde, talvez no reinado de D. Sebastião, as duas prisões refundiram-se em uma só [...]”75.

${ }^{73}$ Sobre este assunto, vide o que dissemos nas pp. 269-272.

${ }^{74}$ Reg. ${ }^{\circ} 1572$, cap. 1 (Ap. Doc., p. 310).

${ }^{75}$ Id., ob. cit., t. I, p. 411. Numa vista topográfica de Lisboa de 1582, de Jorge Braunio, encontra-se representada esta cadeia, sob o $\mathrm{n}^{\circ} 131$. Por ela vemos que estava situada, grosso modo, no centro da cidade, nas proximidades das igrejas de S. Nicolau $\left(\mathrm{n}^{\circ} 83\right)$ e do Espírito Santo da Pedreira ( $\left.n^{\circ} 128\right)$ e do Hospital de Todos os Santos ( $\left.n^{\circ} 10\right)$. Do respectivo desenho, apenas podemos concluir tratar-se de um edifício de pequena dimensão, de planta rectangular e com um telhado de duas águas. $\mathrm{Na}$ vista (parcial) de Lisboa, que retirámos desta mesma descrição e apresentamos na página seguinte, poder-se-á ver este cárcere, assinalado por um círculo. Para uma visão integral da cidade, vide Esteves Pereira e Guilherme Rodrigues, ob. cit., vol. IV, pp. 424-425, onde os autores publicaram a dita vista. 


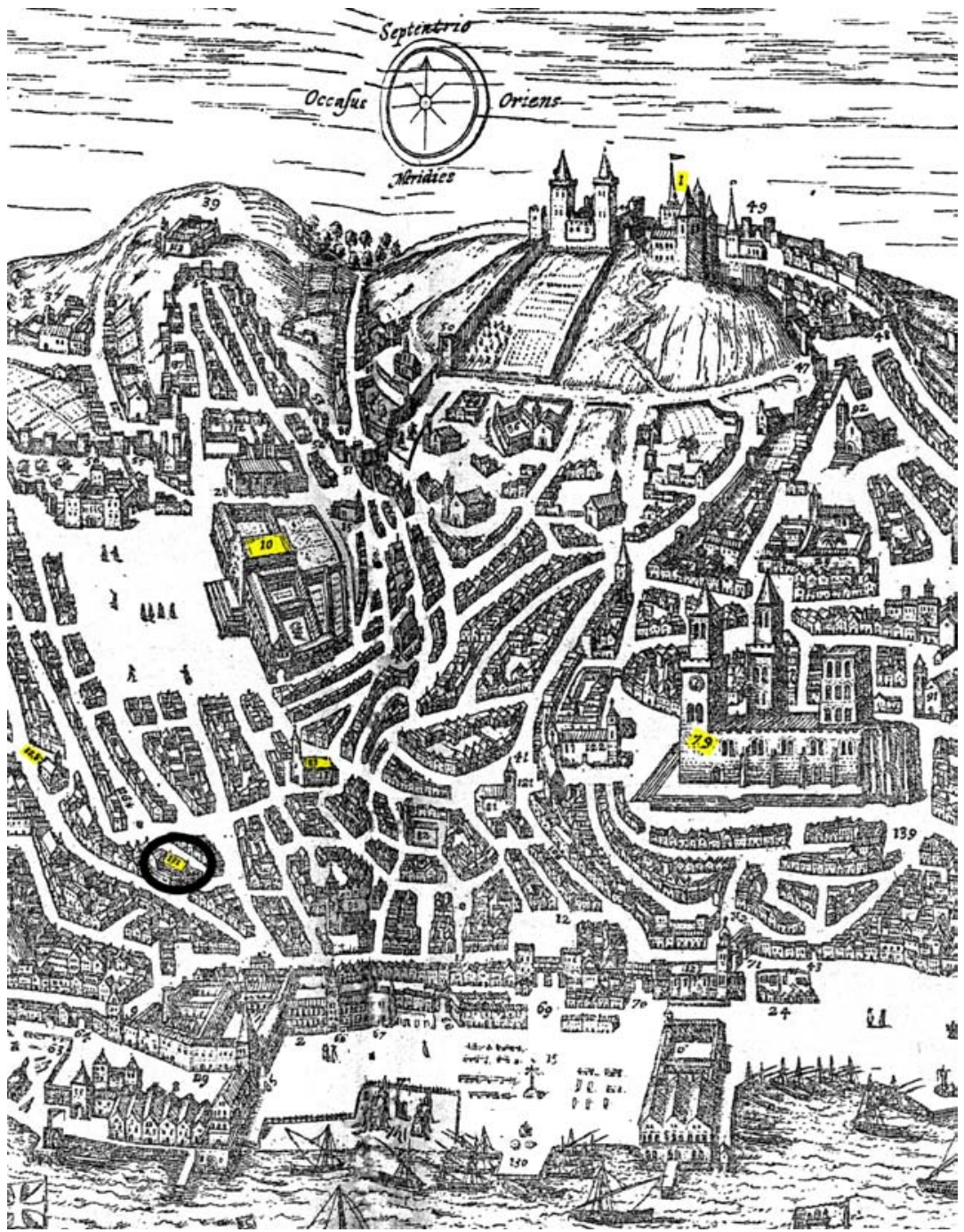

Vista parcial de Lisboa do ano de 1582, tirada do desenho de Jorge Braunio. O edifício à esquerda, assinalado com um pequeno círculo, corresponde à cadeia municipal ou tronco

Legenda: 1 - Castro Real ou Paços do Castelo; 10 - Hospital de Todos os Santos; 79 - Sé; 83 - Igr. de S. Nicolau; 128 - Igr. do Espírito Santo da Pedreira;

131 - Cadeia municipal ou tronco; [...] 
As penas pecuniárias eram da ordem dos 2000 e 4000 réis. A multa de 4000 réis apenas se aplicava num caso, ou seja, para penalizar os acarretadores e moedores que, contrariando o disposto no regimento dos lagareiros, medissem a azeitona dos clientes por cestos ou por outras medidas não autorizadas ${ }^{76}$. Da primeira vez que cometessem esta falta, seriam punidos com a multa de 2000 réis e, em caso de reincidência, com o dobro desta quantia ${ }^{77}$.

Quanto ao destino do produto das multas, que o seu regimento raramente omite, uma parte dele era para a cidade de Lisboa e a outra, para a pessoa que havia denunciado a irregularidade, na proporção de $50 \%$ para cada lado, conforme o costume da época. Os 50\% arrecadados pela Câmara de Lisboa destinavam-se, no todo ou em parte, às obras da cidade.

Se compararmos os quantitativos das multas pagos em Lisboa com os valores exigidos no Regimento dos lagares d'azeyte de Coimbra de 1554, e decerto ainda em vigor em 1572, verificaremos que, nesta última cidade, eles eram bem menos gravosos ${ }^{78}$.

\section{As adições ao Regimento dos lagareiros dos lagares de azeite de 1572}

A promulgação do Regimento dos lagareiros dos lagares de azeite, em 1572, deve ter levantado desde logo algumas críticas, sobretudo da parte dos donos da azeitona, críticas essas que se prendiam, na sua maior parte, segundo cremos, com as disposições relativas aos roubos de azeite e/ou azeitona no interior dos lagares, que eles, decerto, consideravam insuficientes para os impedir. Além disso, havia outras questões, igualmente relevantes, que não haviam merecido a devida atenção da parte do legislador em 1572. Era o caso do valor da fiança a exigir aos mestres lagareiros, antes destes começarem a desempenhar este ofício; do horário de abertura dos lagares ao público; do valor a cobrar pelos donos (ou rendeiros) dos lagares por cada moedura de azeitona neles trabalhada; e também a questão da divisão do bagaço entre ambas as partes, ou seja, entre os donos da azeitona e os proprietários (ou rendeiros) dos lagares.

Na sessão da Câmara de 17 de Outubro de 1575, na qual participaram o seu presidente, vereadores e demais oficiais com assento no Senado, foi "revisto o regimento dos laguares e os apomtamentos que mandarão fazer aos juizes dos lymytes, com pareser do povo, e examinadas as rezois e remedios que se derão pera se tirar quoanto pareceo sofrivel as ocasyois de se furtar o azeite e

\footnotetext{
${ }^{76}$ Sobre a medida padrão adoptada, vide o que dissemos supra, pp. 274-275.

${ }^{77}$ Reg. $^{\circ}$ 1572, cap. 11 (Ap. Doc., p. 312).

${ }^{78}$ Vide $L C$, 1, caps 1-19 (J. Pinto Loureiro, ob. cit., pp. 1-16).
} 
pera se milhor beneficiar e segurar"79. Foi desta vereação, em que se procurou resolver o problema dos furtos sem causar transtornos, que saíram os artigos adicionais ao regimento de 1572, em número de doze, cujo conteúdo passamos a analisar.

\section{Normas relativas à afixação do Regimento dos lagareiros dos lagares de azeite com os aditamentos de 1575 e ao horário de abertura destas oficinas ao público}

A questão da afixação do Regimento dos lagareiros dos lagares de azeite de 1572 já aparece tratada num dos seus artigos, onde se obriga os donos dos lagares a expô-lo, "em taboas pemdurado, pera se poder ver e o leerem todas as pessoas que a elles forem". A necessidade de se dar uma maior divulgação às normas nele consignadas, aliada à proibição de entrada de pessoas estranhas nestas instalações, levou a Câmara de Lisboa a mudar o lugar da sua afixação, transferindo-o do seu interior para a porta de entrada, em lugar que facilmente se pudesse ver e ler. Agora, qualquer pessoa que quisesse inteirar-se do seu conteúdo podia fazê-lo a qualquer hora do dia, e sem quaisquer impedimentos ou favores. A responsabilidade da sua afixação também se transferiu da pessoa do dono do lagar para a do respectivo mestre, conforme vemos nesta passagem das adições: "[...] e este regimento, com ho de que atee guora se usou, se dara encorporado a cada mestre de laguar, o quoall sera obriguado a te-lo pendurado a porta do laguar em parte que fasilmente se posa ver e leer $[\ldots]^{\prime \prime 0}$.

Uma outra questão, sobre a qual a Câmara de Lisboa se debruçou em 1575, diz respeito ao horário de abertura das suas portas ao público. Embora o trabalho dos lagareiros se prolongasse pela noite dentro, as novas disposições ordenam aos donos dos lagares, ou aos seus rendeiros, ou ainda a "outras pesoas per elles,

${ }^{79}$ Vide adições de 1575, Introdução (Ap. Doc., p. 313).

${ }^{80}$ Adições, cap. 12 (Ap. Doc., p. 316). O Regimento dos lagares d'azeyte de Coimbra de 1554 mandava que, em todos eles, existisse um traslado deste documento para que os respectivos senhorios ou os seus rendeiros, ou os representantes deles, se inteirassem do seu conteúdo e o lessem aos mestres e mancebos, quando os contratassem para neles trabalhar. Ponderando-se, posteriormente, quão inconviente era o facto de os mestres não serem obrigados a ter o regimento consigo, determinou-se, por acórdão, que, a partir daí, esta obrigação fosse transferida dos senhorios para eles, a fim de o mandarem ler e ficarem a conhecer as normas por que se deviam orientar no desempenho deste mester. Neste mesmo acórdão, assentou-se que o escrivão da Câmara, antes de lhes dar juramento, devia ler-lhes o seu conteúdo e entregar-lhes um traslado do mesmo, traslado esse que eles deviam ter sempre consigo, quando trabalhassem nos lagares (caps 32 e 38 / J. Pinto Loureiro, ob cit., pp. 11 e 14-15). 
que sejão de boa fama e credito", que fechem as portas da rua ao pôr do Sol e que as abram pela manhã. Esta medida parece ter sido ditada pela preocupação de se evitar a ocorrência de assaltos durante a noite, período durante o qual o movimento nas suas proximidades devia ser reduzido, ou nulo. Numa outra disposição, visando igualmente impedir o roubo de azeite e/ou de azeitona, se aconselha a não se depositar as chaves dos lagares nas mãos de "pesoas que não sejão de comffiamça" ${ }^{\text {"1 }}$.

No Regimento dos lagares d'azeyte de Coimbra de 1554, mandava-se aos mestres lagareiros que, quando aqueles estivessem parados e existisse azeite no seu interior, fechassem à chave as talhas que o continham e entregassem as respectivas chaves, ou as chaves das portas dos lagares, aos donos do azeite, declinando-se, assim, para estes, a responsabilidade da sua guarda ${ }^{82}$. É provável que a recomendação das adições do Regimento dos lagareiros dos lagares de azeite de Lisboa, no tocante à entrega das chaves dos lagares a particulares (donos do azeite?), tivesse sido motivada por esta mesma preocupação.

\section{Normas relativas ao pessoal que trabalhava nos lagares e à sua alimentação}

No que diz respeito ao pessoal que trabalhava nos lagares, a Câmara de Lisboa, em 1575, procurou colmatar algumas lacunas verificadas no Regimento dos lagareiros de 1572, nomeadamente no que tocava ao ofício de mestre. Neste regimento, a atenção do compilador havia-se fixado nos requisitos que deviam satisfazer todos aqueles que pretendessem desempenhar este mester, ou seja, no exame de mestria, na carta de mestre, na fiança e no seu juramento na Câmara ${ }^{83}$. Nas adições de 1575, vai-se um pouco mais além, dando-se aos encartados mais algumas indicações para o exercício deste ofício. Assim, nos anos de azeitona, antes de os lagares começarem a laborar, deviam apresentar-se na Câmara de Lisboa com as respectivas cartas de mestre e fianças, para aí obterem os respectivos vistos e prestaram o juramento que o Regimento de 1572 exigia a todos eles.

As cartas de mestre eram revistas por um vereador da Câmara, designado para o efeito, que nelas punha o visto, e não só! A partir de agora, passou-se a exigir que em todas elas estivesse mencionada a idade e alguns sinais dos respectivos possuidores, para que estes pudessem ser identificados. Com a

\footnotetext{
${ }^{81}$ Adições de 1575, cap. 6 (Ap. Doc., p. 315).

${ }^{82}$ LC, 1, Regimento dos lagares d'azeyte, cap. 21 (J. Pinto Loureiro, ob cit., p. 8).

${ }^{83}$ Sobre este assunto, vide supra, pp. 269-272.
} 
inclusão destes elementos, procurava-se decerto evitar que estes "diplomas", por omissão de dados pessoais, pudessem eventualmente ser usados por outras pessoas com os mesmos nomes ${ }^{84}$.

No que diz respeito à fiança "abonada", que os mestres lagareiros deviam dar de "todos os danos e perdas e penas dentro do lymite do laguar", esta aparece agora fixada na quantia de 100000 réis. O Regimento de 1572 havia-se limitado a exigir dos mestres a satisfação deste requisito, sem apontar, no entanto, qualquer quantitativo para ele. $\mathrm{O}$ valor desta fiança, para estes e outros oficiais mecânicos "que recebem do alheo", até 100000 réis, aparece fixada numa postura camarária desta altura, ou entretanto promulgada:

"Foi acordado que todos os corretores, ouriuezes, [...] e todos os outros mais officiaes $\tilde{\mathrm{q}}$ recebem do alheo deem fiança na Camara desta cidade, como esta ordenado pelas posturas antigas. A qual fiança darão na Camara ao escriuão della em cada hũ anno no mes de Abril, tirando porẽ os corretores de mercadorias [...] e as fianças que as sobreditas pessoas derem serão nesta quantia: [...]. E todos os mais officiaes assi dos acima ditos como outros quaesquer que receberem do alheo darão fiança ate cem mil rs. As quaes fiãças durarão do dia que as derem em qualquer tempo que seia a hũm anno, e o fiador ficaraa obrigado a pagar tudo aquillo de que não der cõta a pessoa que assi fiou do dia que der a fiança a hũ anno como dito he e $[\ldots]^{\prime 85}$.

Quanto à data de apresentação da fiança pelo mestre - no mês de Abril, segundo a postura supra -, verificamos que, devido à especificidade deste ofício, o cumprimento desta obrigatoriedade tinha lugar nas proximidades da abertura dos lagares, provavelmente no mês de Outubro ou Novembro. Mais tarde (séc. XVII ?), esta abonação deixou de ser dada na Câmara ao respectivo escrivão, para passar a ser concedida ao dono do lagar, e de ser obrigatória. A sua apresentação passou a depender tão-somente da vontade dos senhorios dos lagares, que podiam exigi-la ou não, consoante a confiança que depositavam nas pessoas que contratavam para mestres dos seus lagares. Como era sobre eles que recaía a obrigação de indemnizarem os donos da azeitona dos prejuízos causados pelos mestres, caso estes não pudessem ou quisessem fazê-lo, foi-lhes dada a possibilidade de exigirem uma fiança antes de os admitirem ao seu serviço ${ }^{86}$.

${ }^{84}$ Adições de 1575, cap. 1 (Ap. Doc., p. 313).

${ }^{85}$ LROM, Livro segundo de posturas geraes para os officiaes mecanicos, cap. X - Das fianças que são obrigados [a] dar na Camara os officiaes q̃ recebẽ do alheo (Dr. Vergílio Correia, ob. cit., pp. 237-238).

86 "O dito mestre sera obrigado a dar fiança ao dono do lagar se lh' a pedir pera que, havendo falta da sua parte, asim na bondade do azeite como na quantidade, tenha o dono do lagar por onde 
As actividades dos mestres e acarretadores, sobre os quais recaía a suspeição de furtarem azeitona e azeite aos fregueses dos lagares, foram igualmente analisadas na sessão da Câmara de 17 de Outubro 1575, de onde saíram algumas normas tendentes a impedir (ou a minimizar) estas ocorrências, que constam das adições que estamos a analisar, e de que daremos conta no item seguinte.

Nesta mesma reunião da Câmara, se analisou a questão relacionada com a alimentação dos lagareiros - que o regimento de 1572 não havia tratado -, conjuntamente com a compensação a cobrar por cada moedura de azeitona. Nela se assentou, à semelhança do que se verificava na indústria oleícola de Coimbra $^{87}$, que o pessoal dos lagares passasse a ser alimentado pelos respectivos donos, ou rendeiros: “[...] E os ditos donos dos laguares e remdeiros delles serão obriguados a dar de comer aos laguareiros, moedor e acaretador [...]"88.

\section{Normas relativas ao recebimento, acondicionamento, à medição e ordem de moagem da azeitona (vez)}

Nas adições ao Regimento dos lagareiros dos lagares de azeite, a Câmara de Lisboa voltou a debruçar-se sobre as questões relacionadas com o recebimento e o acondicionamento da azeitona nos lagares, sua medição e ordem de moagem (vez). No que diz respeito às duas primeiras questões, o referido regimento havia-se limitado a ordenar que, em todos os lagares de azeite, houvesse "tulhas bem repartydas em que se bem posão recolher cimquoenta moeduras de azeytona, que se podem fazer em huum mes", o que dá uma média de duas moeduras por dia, não se entrando em linha de conta com os domingos ${ }^{89}$. A forma lacónica como esta norma foi redigida deve ter levantado alguns problemas, no tocante à sua aplicação. Um desses problemas prendia-se, decerto, com a questão de se saber se a azeitona dos fregueses devia ser recebida tão-somente de mês a mês, quando todas as tulhas do lagar estivessem desocupadas, ou à medida que estas se iam esvaziando. Esta segunda hipótese, para a qual nos inclinamos, levanta, também ela, duas questões: uma delas respeitante à quantidade de azeitona que se podia receber de cada vez, ao longo do mês, e a outra à existência de azeitona

se pagar da perda que o mestre der. E o dito dono estara sempre obrigado as partes a satisfação da dita perda e da que, por qoalquer via, tiver no lagar o dono da azeitona" (Regimento de lagar de azeite, cap. 3 / Artur Salvado, ob. cit., pp. 50-51).

${ }^{87}$ Vide LC, 1, Regimento dos lagares d'azeyte, cap. 1 (J. Pinto Loureiro, ob cit., pp. 1-3).

${ }^{88}$ Adições de 1575, cap. 10 (Ap. Doc., pp. 315-316).

${ }^{89} \mathrm{Reg}^{\circ}{ }^{\circ} 1572$, cap. 9 (Ap. Doc., p. 311). No que respeita à quantidade de azeitona triturada, as duas moeduras por dia estão de acordo com a realidade coimbrã (vide supra, pp. 275-276). 
amontoada nos lagares, fora das tulhas, à espera de vez para ser entulhada ou moída.

Pelas razões que apontámos, impunha-se a regulamentação desta disposição de forma mais explícita, o que viria, de facto, a verificar-se em 1575. Num dos Capitullos que se acrecentarão no Regimento dos laguareiros neste ano, proibiu-se os mestres de receber azeitona nos lagares, no caso de não houver tulhas disponíveis para ela: "[...] não receberão allgũa azeytona no laguar, senão depois de não aver outra nas tulhas [...]"90 . A hipótese de se receber azeitona, para além da capacidade das tulhas, foi, em princípio, excluída. Em 1575, ou seja, três anos depois da promulgação do Regimento dos lagareiros dos lagares de azeite, os lagares de Lisboa e termo já deviam estar apetrechados de tulhas com capacidade para as cinquenta moeduras de azeitona, conforme se exigia numa das suas disposições, pois, caso contrário, a Câmara de Lisboa não autorizaria a sua abertura, segundo cremos.

A disposição de 1575, acima referida, vem acompanhada de uma outra, que limita a quantidade de azeitona, que se podia receber de cada vez, àquela que se podia "moer dentro em quoatro e quoatro dias", o que corresponde a uma média de oito moeduras, ou seja, a 560 alqueires ${ }^{91}$.

Conciliando o conteúdo dos dois capítulos que tratam deste assunto, o do Regimento dos lagareiros dos lagares de azeite de $1572^{92}$ e o das suas adições de $1575^{93}$, somos levados a supor que as cinquenta moeduras de azeitona, a que a primeira fonte faz alusão, estariam repartidas nos lagares, no mínimo, por seis tulhas, cada uma delas com a capacidade de armazenamento correspondente a oito moeduras de azeitona. E à medida que estas tulhas se fossem esvaziando, por ordem de entrada da azeitona nos lagares, os mestres podiam receber igual quantidade para repor os stocks: "E não tomara [sic] mais per jumto a outras partes de fora, que a que se pode moer dentro em quoatro e quoatro dias" 94 . A Câmara de Lisboa justifica esta disposição com os seguintes argumentos: para se evitar que a azeitona fora das tulhas arrefecesse, o que dificultaria a sua moagem bem como a extracção do seu azeite ${ }^{95}$; para se evitar que a

${ }^{90}$ Adições de 1575, cap. 4 (Ap. Doc., p. 315).

${ }^{91}$ A propósito desta quantidade de azeitona, vide supra, pp. 275-276.

${ }^{92}$ Reg. ${ }^{\circ} 1572$, cap. 9 (Ap. Doc., p. 311).

93 Adições de 1575, cap. 4 (Ap. Doc., p. 315).

${ }^{94}$ Id., cap. 4 (Ap. Doc., p. 315$)$.

${ }^{95} \mathrm{O}$ capítulo 4 das adições de 1575 , ao fazer referência ao arrefecimento da azeitona nos lagares quando fora das tulhas, leva a supor que a mesma já havia estado entulhada em casa dos respectivos donos. Com a azeitona "fresca", vinda directamente dos campos, não se verificaria, decerto, este fenómeno. A azeitona entulhada, não obstante o sal que levava para não apodrecer, 
azeitona, durante muito tempo amontoada algures nos lagares, à espera de vez, se fosse "guastando", ou seja, mirrando, devido à perda da água de vegetação; e finalmente, para se evitar que a azeitona dos fregueses, fora das tulhas, ou o seu azeite, se pudessem misturar ou confundir. De acordo com o conteúdo das duas normas, a azeitona podia estar entulhada nos lagares, à espera de vez para ser moída, perto de um mês, o que implicava o recurso ao sal para que, entretanto, se não estragasse ${ }^{96}$.

O cumprimento desta norma das adições parece, no entanto, ter ficado condicionado à vontade dos donos da azeitona, conforme se conclui da sua parte final, que indicamos em itálico na transcrição que dela fazemos a seguir: "Item, não receberão allgũa azeytona no laguar senão depois de não aver outra nas tulhas, e não tomara [sic] mais per jumto a outras partes de fora que a que se pode moer dentro em quoatro e quoatro dias, por se não estar areffecemdo e guastando e não mesturar hũa com outra, ou dar huum azeyte por outro, senão comsentyndo-o seus donos d'azeitona que se mesture, ou que se tragua prymeiro que seja acabada a que esta no laguar [...]"97. Em suma, a Câmara de Lisboa legislou no sentido de impedir a existência de azeitona amontoada nos lagares, fora das tulhas, pelas razões que referimos, mas depois faz depender o cumprimento desta disposição da vontade dos donos da azeitona, quer da azeitona entulhada nos lagares, quer fora deles.

No que diz respeito à medição da azeitona, o Regimento dos lagareiros dos lagares de azeite de 1572 já se havia debruçado sobre este assunto, ordenando aos acarretadores e moedores que utilizassem nesta operação tão-somente a meia fanga. A medição por $\operatorname{cestos}^{98}$ não era permitida, e a meia fanga de azeitona

ao fim de alguns dias de amontoamento nas tulhas, aquecia, o que, na opinião dos antigos oleicultores, era benéfico não só pelo facto de se moer melhor, mas também pela circunstância de largar mais facilmente o óleo que continha. Simplesmente, o aquecimento da azeitona também tinha o inconveniente de alterar a qualidade do seu azeite, sobretudo quando a sua permanência nestes depósitos se prolongava por vários meses (vide, sobre este assunto, João António DallaBella, ob. cit., p. 25 e segs).

${ }^{96}$ Nos anos de boas colheitas, o tempo de entulhamento da azeitona podia prolongar-se por cinco ou seis meses, conforme aconteceu no de 1781: como neste ano houve uma produção abundante, os lagares existentes não puderam despachá-la dentro do período normal de laboração (sobre o entulhamento e a conservação da azeitona, vide João António Dalla-Bella, ob. cit., p. 25 e segs, e Ramiro Larcher Marçal (relator), "Conservação da azeitona; entulhamento e sua influência na qualidade dos azeites comestíveis", em Congresso de leitaria, olivicultura e indústria do azeite em 1905. Relatório Geral, vol. II, Cultura da oliveira - Material e processos do fabrico do azeite, Lisboa, Imprensa Nacional, 1906, 2a Parte, pp. 1-10 e 313-328).

${ }^{97}$ Adições de 1575, cap. 4 (Ap. Doc., p. 315).

${ }^{98}$ Segundo o P. ${ }^{\mathrm{e}}$ Rafael Bluteau, trata-se de um "vaso de vimes, grande \& fundo" (Id., ob. cit., s.v. "Cesto", vol. II, p. 260). 
devia ser "avellada e não callcada" 99 . Em 1575, a Câmara voltou a debruçar-se sobre esta matéria, proibindo expressamente os carreteiros de medir a azeitona por cestos. Continuam a só poder utilizar a "medida de rasoura", ou seja, a meia fanga rasoirada, e a não poder calcar a azeitona com a mão ou com a pá "com que lanção $[a]$ azeytona sobre a medida" ou com qualquer outra coisa, conforme agora se precisa ${ }^{100}$.

Quanto à ordem de moagem da azeitona (a vez), em 1575 a Câmara voltou a abordar este assunto, mas tão-somente para introduzir a pena de "dous mill reis e da cadea" para os mestres que a não respeitassem, em virtude de esta estar omissa no Regimento dos lagareiros dos lagares de azeite de 1572. No resto, não houve qualquer outra alteração, relativamente ao que este regulamento havia prescrito sobre esta matéria: "Item, os mestres dos laguares serão obryguados a moer prymeiro $[a]$ azeytona que prymeiro vier per sua ordem, salvo se ho dono da dita azeytona comsentir que se faça a outra que depois vier em luguar da sua, sob a dita pena $[\ldots]^{\prime \prime 101}$.

\section{Normas tendentes a evitar perdas ou roubos de azeite no interior dos lagares por parte dos lagareiros}

As adições ao Regimento dos lagareiros dos lagares de azeite de 1572 foram ditadas, em grande parte, pela preocupação de se evitarem perdas ou roubos de azeite no interior dos lagares, por descuido ou má fé dos respectivos lagareiros. Daí, o conjunto de medidas que foram adoptadas pela Câmara de Lisboa na reunião de 17 de Outubro de 1575, relativas às sertãs (sartaans) e à partilha, medição, empréstimo, venda e transporte de azeite, por parte dos mestres e acarretadores.

A alusão a sertãs requer uma explicação prévia acerca daquilo que a palavra designa, uma vez que os dicionários e enciclopédias apenas lhe atribuem o significado de frigideira, ignorando o do documento que estamos a analisar.

${ }^{99}$ Reg. $^{o} 1572$, cap. 11 (Ap. Doc., p. 312). Sobre este assunto, vide supra, pp. 274-275. Relativamente à palavra avellada, pensamos que, neste contexto, tenha o significado de solta.

${ }^{100}$ Adições de 1575, cap. 8 (Ap. Doc., p. 315).

${ }^{101}$ Id., cap. 11 (Ap. Doc., p. 316). A ordem de moagem (a vez) nem sempre era respeitada pelos senhorios dos lagares, o que dava origem a queixas da parte dos lesados. Em Coimbra, "por se queyxar o povo que os senhorios dos lagares deyxavam de fazer os azeites que neles tinhão e tomavam outras pilhas que estavão em outras partes, fora dos taaes lagares", acordou-se, em 1554, "que atee nom acabarem de fazer as pilhas que teverem nos lagares, nom posão tomar nem fazer outra n[en]hũa, que fora do seu laguar estee", sob pena de pagarem 1000 réis "por cada vez que fezerem o contrario" (LC, 1, Regimento dos lagares d'azeyte, cap. 37 / J. Pinto Loureiro, ob cit., p. 14). 
No caso em questão, trata-se de um tanque feito de tijolos rebatidos ${ }^{102}$, revestido de lajes e com um lancil de cantaria, construído sobre as fornalhas dos lagares de azeite e destinado à cozedura e purificação deste óleo. Nesta altura, havia dois tipos de lagares de azeite, denominados de sertã e de água, que se distinguiam entre si pela técnica de extracção e purificação do azeite, neles praticada. Aos de água, também se dava a designação de lagares de calda ou de caldeira. A origem de ambos os lagares perde-se na grande "noite do tempo". Em Portugal, temos notícia da sua existência na cidade de Évora em $13922^{103}$.

No tocante aos lagares de sertã, um documento da Ordem de Santiago de 1819 diz-nos que neles "se obrava a factura delle [azeite] para a sua extracção, por meio de hum fogo activo existente debaicho da certãa [...]"104. Portanto, nos lagares de sertã, o azeite misturado com alguma água de vegetação da azeitona, que saía da massa enseirada devido à força compressiva da prensa, era recolhido em potes, sendo depois despejado num tanque (sertã). Aqui, por acção do calor da fornalha, se ia libertando das águas e impurezas que continha, bem como do sabor herbáceo característico dos azeites novos. Passado o período de cozedura e repouso, que se prolongava por várias horas, arrecadava-se o azeite em grandes jarras de barro ou odres, dentro dos quais seguia para casa dos respectivos donos, e escoavam-se as águas e as fezes que se haviam acumulado na parte inferior da sertã. No capítulo sétimo das adições de 1575, mandava a Câmara aos donos (ou aos rendeiros) dos lagares que tivessem muito cuidado com elas, para que se não verificassem perdas de azeite ou o abaixamento da sua temperatura: “[...] que sejão bem vedadas e tenhão suas cobertas de esparto boas, com que bem cubrão, pera que se não perqua ho azeite, e este milhor comservado e mais quente $[\ldots]^{\prime \prime 105}$.

${ }^{102} \mathrm{O}$ tijolo rebatido corresponde, segundo cremos, ao que hoje designamos por tijolo burro. No Regimento dos oleiros da cidade de Lisboa de 1572 alude-se a este tipo de tijolos, que era usado para este e outros fins (LROM, cap. XLIII - Do Regimento dos Oleiros / Vergílio Correia, ob. cit., p. 145).

${ }^{103}$ No Regimento da cidade deste ano, $T .{ }^{\circ}$ XXIV - Dos Lagares do azeite, estipulou-se o seguinte: que "o lagareiro leve de moajem se for de sartaan de dez hum [...] e tres paães e IIII. rs. de lenha. E se for de calda de dez e seis hum. [...]. It. leve mais pera a besta pera moedura de sertan meo alqueire de cevada. E pera moedura de calda sob pena suso dita [um alqueire] [...]" ( Gabriel Pereira, ob. cit., Primeira Parte, p. 183).

${ }^{104}$ IAN/TT-Ordem de Santiago, liv. 34, fl. 34v.

${ }^{105}$ Adições de 1575, cap. 7 (Ap. Doc., p. 315). A consulta que realizámos há anos nos I. L. B. (Inquéritos Linguísticos Boléo, Coimbra, Faculdade de Letras - Instituto de Língua e Literatura Portuguesas, 1942-1974) foi fundamental para a compreensão do que eram os antigos lagares de sertã, de que ainda havia reminiscências no século passado, como se pode ver no desenho de um lagar de azeite existente em Suçães (c. Mirandela) em 1942 (vide Ap. Doc., fig. 1). 
Quanto aos lagares de calda ou caldeira, o documento da Ordem de Santiago, atrás referenciado, também nos dá algumas indicações a seu respeito, ao dizer que neles "a extracção do azeite se fazia por meio de agoa fervente e aonde não havia perda alguma das partes oleozas, por não haver fogo que as consumisse"106. Neste tipo de lagares, que o autor desta fonte põe em paralelo com os de sertã para mostrar a sua vantagem sobre estes, após o primeiro aperto da massa da azeitona, sem água quente e geralmente pouco demorado, a vara da prensa era levantada; a massa das seiras remexida e regada com água fervente e, de novo, submetida à acção da prensa. É provável que esta operação se repetisse uma segunda vez. Neste caso, a massa da azeitona era prensada três vezes, e caldeada com água a ferver, ou quase, duas outras ${ }^{107}$.

Segundo João António Dalla-Bella, o uso de água fervente era um bom processo para fazer sair o azeite da massa da azeitona, embora tivesse contra si o facto de aumentar muito a má qualidade deste óleo. Daí que, em sua opinião, só se devesse recorrer a este expediente na terceira espremedura da massa, onde "naõ se deve attender tanto á qualidade do azeite, mas sim á quantidade maior que se póde tirar"108. Este azeite, impróprio para a alimentação humana, destinar-se-ia, na sua maior parte, à iluminação e à indústria da saboaria, conforme já referimos.

Neste tipo de lagares, é provável que já em 1392 se praticasse a repisa da "baguaça" antes de se lhe dar o último banho e aperto na prensa. Na verdade, só assim se compreende o porquê de, no regimento dos lagareiros de Évora deste ano, se exigir aos donos da azeitona o dobro da cevada (um alqueire por moedura) que se pagava nos lagares de sertã (meio alqueire), destinada às bestas que moviam as galgas nos lagares de sangue.

${ }^{106}$ IAN/TT - Ordem de Santiago, liv. 34, fl. 34v.

${ }^{107}$ No Regimento dos lagares d'azeyte de Coimbra de 1554, exigia-se aos mestres que fossem "bem delygenttes em daar todolas as caldas aos azeites que lhe $[s]$ forem necesarias, em taal maneira que por sua culpa o azeite nam [se] perqua", sob pena de serem multados e terem de indemnizar os donos da azeitona por si lesados (cap. 22 / J. Pinto Loureiro, ob cit., p. 8). Segundo este mesmo regulamento, "huum dos gramdes males e gramde perda que o povo recebe no fazer de seus azeites asi he pollos mestres dos dittos lagares nom deixarem moer $[a]$ azeitonna segumdo deve ser e escousar a masa segumdo merece. E muytas vezes se tem visto e achado ser a baganha tão mal moyda e escousada que hee cousa vergonhosa e dinna de bom castigo, [...]" (cap. 30 / J. Pinto Loureiro, ob. cit., p. 11). Os mestres que procedessem desta maneira e fossem denunciados, além de serem presos, seriam obrigados a indemnizar os donos da azeitona lesados e a pagar uma multa de trezentos réis, a reverter para a pessoa que os havia denunciado, entre outras penas.

${ }^{108}$ Id., ob. cit., p. 92. 
A mistura de água e azeite, que saía das seiras à medida que a prensa as ia comprimindo com a sua vara e peso ${ }^{109}$, ia ter a uma caldeira, onde o azeite sofria um novo escaldão, agora para lhe tirar o sabor amargo e libertá-lo das impurezas que continha. Era nesta caldeira que se dava a separação do azeite das mucilagens, separação essa que o mestre procurava abreviar, mexendo a mistura com uma vara fina ou com um raminho de pinheiro ou de uma outra árvore. Terminada esta operação, os dois líquidos ficavam a repousar durante várias horas, para que a depuração do azeite continuasse a processar-se por mais algum tempo. O azeite, por se não misturar com a água e ser menos denso que esta, subia na caldeira, enquanto as águas e a maior parte das impurezas se acumulavam no fundo, de onde eram esgotadas para o exterior através de um pequeno orifício, nela existente.

No Vocabulario Portuguez e Latino, o $\mathrm{P}^{\mathrm{e}}$ Rafael Bluteau deixou-nos uma curiosa descrição do processo que era usado por alguns lagareiros do seu tempo para esgotarem a água ruça e as mucilagens da azeitona, que se haviam ajuntado no fundo da caldeira (tarefa). Diz-nos este autor: “[...] \& o Lagareyro mettendo hum pè por baixo em huma barroca, em que está o fundo da Tarefa, lhe destapa com o dedo polegar hum buraco, que esta tem no fundo \& tendo o dito dedo no buraco está deixando pasar a agoa ruça, até conhecer pelo toque no dedo, que o azeite está chegado a elle, \& então com o mesmo dedo deyxa tapado o buraco, que com elle destapou [... $]^{\prime 110}$, não devendo, por conseguinte, retirá-lo daí, enquanto houvesse azeite na tarefa, para que este se não escapasse por esta abertura.

${ }^{109}$ Pedra geralmente do formato de um cone circular truncado, algumas delas com várias centenas de quilos de peso, que fazia parte das prensas de varas dos antigos lagares de azeite e de vinho (vide $A p$. Doc., fig. 4, onde apresentamos a fotografia de um destes exemplares que chegou até nós).

${ }^{110}$ Id., ib., s.v. "Azeite". A água ruça que saía dos lagares de azeite era motivo de grande preocupação para as autoridades camarárias, sobretudo quando estas instalações se encontravam localizadas às portas das cidades ou nas suas proximidades, como acontecia em Coimbra (António de Oliveira, ob. cit., vol. I, pp. 503-504). Daí a razão de o Regimento dos lagares d'azeyte desta cidade de 1554 fazer recair sobre os respectivos mestres a responsabilidade de "terem as aguoas d'albufeyra em cavouquos gramdes e bem vedados, em taal maneira que não possão deles sair senão a bom recado, por ser cousa muitto odiosa e perigosa pera o povo e a não soltaram senam hũa ora amdada da noyte, sob penna de myl reis, [...] e atee a dita ora da noyte a sollttaram, e não dahy pera diamte, sob a dita penna. E dahy a duas oras a taparão, sob a mesma penna" (cap. 23 / J. Pinto Loureiro, ob. cit., p. 9). O Regimento dos lagareiros dos lagares de azeite de Lisboa de 1572 nada refere sobre este assunto, embora, na safra do ano anterior, se tenha levantado uma questão entre a Câmara de Lisboa e Maria Monteiro, proprietária de um lagar de azeite nesta cidade, por motivo do rebentamento de um cano de escoamento das suas águas numa rua pública (IAN/TT Mosteiro de S. Vicente de Fora, cx. 9, m. 25, no 43). 
A espuma e alguns pedaços de massa de azeitona que sobrenadavam o azeite eram retirados pelo mestre com um pequeno vaso de barro ou uma simples concha do mar. Quando existiam duas caldeiras ou tarefas, uma ao lado da outra (o que talvez ainda se não verificasse em 1572), à medida que o azeite ia subindo, ia passando para a do lado (o chamado pote do azeite), através de uma pequena caleira existente entre elas que, nalguns casos, poderia ser uma mera telha.

Amais antiga descrição deste processo de extracção do azeite, recolhemo-la no Vocabulario Portuguez e Latino [...] do Pe Raphael Bluteau, que diz o seguinte: "[...] A agoa ruça das azeitonas. He a que a azeitona tem em si, a qual se acrescenta com a agoa fervendo, que vay da caldeyra, \& se lhe lança, quando a maça das azeitonas está nas ceyras \& com as mexeduras, que lhe dão, lança a dita maça a agoa ruça de si \& a que lhe lançavam fervendo, \& azeite tudo misturado por força da vara, \& peso, que se lhe poem, \& corre tudo para as Tarefas, \& com outras agoas ferventes, que se lanção nas Tarefas; se separa a agoa ruça do azeite, \& se purifica este ficando separado da agoa ruça na dita Tarefa, no fundo da qual se acha toda a dita agoa, \& o lagareyro $[\ldots]^{\prime \prime 11}$

Uma vez concluído o processo de extracção e depuração do azeite, o mestre retirava-o da caldeira com um pequeno vaso de barro, que ia despejando num maior, que servia de medida. Este último, o chamado "pote de medir o azeite", uma vez cheio, era vazado nas talhas ou potes de barro, existentes no lagar, ou em odres, destinados ao seu transporte até casa dos respectivos donos. A venda de azeite fazia-se, muitas vezes, com ele ainda quente, sobretudo quando transacionado nos lagares, ou frio de poucos dias.

Quanto à tipologia dos lagares de azeite de Lisboa na segunda metade do século XVI, não obstante as adições ao Regimento dos lagareiros dos lagares de azeite de 1572 aludirem à existência de sertãs nestas instalações, não sabemos precisar se estamos em presença de lagares de sertã ou de água, embora nos inclinemos para a primeira hipótese, devido à exigência de haver nelas potes em número suficiente para a recolha do azeite cru. A nossa hesitação, talvez injustificada, deriva do facto de alguns lagares de calda terem conservado as

${ }^{111}$ Id., ib., s. v. "Azeite”. Para mais pormenores sobre este assunto, vide João António DallaBella, ob. cit., pp. 49-52. É provável que, por este processo de extracção, se obtivessem duas qualidades de azeite: o azeite virgem ou flor, proveniente da primeira espremedura da massa a frio, e o azeite comum, resultante da segunda, ou da segunda e terceira espremeduras. É provável, também, que nem sempre houvesse a preocupação de separar o azeite comum do azeite ordinário, ou seja, do azeite da última espremedura do bagaço. 
sertãs dos antigos lagares desta tipologia, mas agora destinadas ao escaldão do azeite com água fervente, processando-se o seu batimento e separação da água ruça e impurezas num pote ou caldeira, para onde, entretanto, a mistura havia passado. Por volta de meados do século XX, ainda havia lagares de calda com sertãs, no actual distrito de Bragança ${ }^{112}$.

Uma vez caracterizados os dois tipos de instalações oleícolas existentes na segunda metade do século XVI, voltemos à análise dos capítulos que foram acrescentados ao Regimento dos lagareiros dos lagares de azeite em 1575. Neste ano, as autoridades municipais de Lisboa, preocupadas com o problema do desvio de azeite nos lagares, tomaram várias medidas no sentido de impedir estas ocorrências, uma delas respeitante à partilha do azeite. Esta só poderia ser feita pelo mestre lagareiro na presença do respectivo dono, do proprietário do lagar (senhorio) ou do rendeiro deste ou, ainda, dos seus procuradores. A presença do senhorio ou do rendeiro (ou dos representantes destes) justificava-se pelo facto de uma parte do azeite extraído nos seus lagares, correspondente a $10 \%$, lhes pertencer a título de maquia. Os mestres que violassem o conteúdo deste artigo seriam punidos com a multa de 2000 réis $^{113}$.

O empréstimo e a venda de azeite estavam-lhe igualmente defesos, bem como a sua intervenção neste último negócio, sob a dita pena dos "dous mill reis paguos do tronquo". Somente os donos do azeite o poderiam fazer. E a verificar-se esta venda no lagar, o mestre devia exigir ao comprador que o levasse "loguo fora [dele] peramte ho dito vemdedor ou seu procurador"114.

No que diz respeito ao vasilhame, não era permitida a existência de vasilhas de compradores de azeite no lagar, salvo na altura da compra, nem ao mestre pôr azeite em vasilhas que não fossem do proprietário do lagar (senhorio $)^{115}$.

${ }^{112}$ Vide $A p$. Doc., fig. 1, onde apresentamos um desenho de um desses lagares.

${ }^{113}$ Adições de 1575, cap. 3 (Ap. Doc., p. 313). O Regimento dos lagares d'azeyte de Coimbra também exigia aos donos do azeite que estivessem presentes no acto da sua medição, eles ou alguém por eles mandatado para este efeito. Em relação à medição propriamente dita, ordenava aos mestres que o fizessem com "a medyda justa e não com verteduras, asi o que emtregarem a seu dono do azeite, como o que ouverem d'aver de maquia [...] sob pena de, [...] pagarem trezentos reis de penna [...]" No caso de os donos da azeitona não comparecerem à medição do azeite nem enviarem pessoas em seu lugar para assistir a esta operação, os mestres poderiam fazê-lo sem a sua presença para que os engenhos não ficassem parados por falta de talhas para o azeite, e desde que de tudo dessem "fielmente conta" (caps 12 e 13 / J. Pinto Loureiro, ob cit., p. 6).

${ }^{114}$ Adições de 1575, caps 2 e 5 (Ap. Doc., pp. 313 e 315).

${ }^{115}$ Id., cap. 5 (Ap. Doc., p. 315). 
Nestas adições, também se proibiu o transporte de azeite pelos carreteiros dos lagares. É provável que esta medida tivesse em vista impedir que estes transportes fossem aproveitados pelos lagareiros para desviarem azeite das respectivas instalações ${ }^{116}$.

Este conjunto de medidas, com as quais a Câmara de Lisboa pretendeu, em 1575, evitar o desvio de azeite nos lagares, parece não ter posto termo a estas ocorrências por parte dos lagareiros mais expeditos, conforme se conclui do facto de o respectivo senado ter continuado a legislar sobre esta matéria. Num regimento posteriormente promulgado, recomendava-se aos almotacés das execuções que, nas suas visitas a estas instalações para fins de correcção, verificassem se as medidas estavam aferidas desse ano, e se o pote de medir o azeite tinha " algum buraco ou, por dentro, algum pedaço de casca de coco ou cortiça que faça enchimento para levar menos azeite [...]"117.

\section{Normas relativas à fixação do custo da moedura e à repartição do bagaço entre os donos da azeitona e os proprietários ou rendeiros dos lagares}

A Câmara de Lisboa, nas adições ao Regimento dos lagareiros dos lagares de azeite, também se preocupou com a questão do custo da moedura da azeitona (que este regulamento não havia abordado), a fim de evitar grandes divergências de lagar para lagar, bem como a consequente concorrência entre eles. De acordo com o estipulado no capítulo 10 das adições, os senhorios dos lagares podiam cobrar, por cada moedura de azeitona, a décima parte do azeite extraído, acrescida da quantia de cinquenta ou sessenta réis em dinheiro. No que diz respeito à parte alíquota do azeite que lhes cabia, mandou que se cobrasse do bom e do mau, "e não [apenas] dos olhos delle", ou seja, em nosso entender, tão-somente do azeite da parte de cima das sertãs ou potes, que era o de melhor qualidade. Quanto aos quantitativos em dinheiro por "moer cada moedura" de azeitona, limitou-se a fixar os valores até aí praticados nos lagares, ou seja, "sesemta reis nos laguares omde atee guora se não custumou levar menos dinheiro, porque, honde se costumou atee guora levar a cimquoenta reis, não levarão mais". E como em algumas destas instalações se cobrava, indevidamente, uma canada e meia de azeite (2,1 litros), dito "do cabaço",

\footnotetext{
${ }^{116}$ Id., cap. 8 (Ap. Doc., p. 315).

${ }^{117}$ Regimento de lagar de azeite, cap. 9 (publ. Artur Salvado, ob. cit., pp. 52-53). O pote tinha a capacidade de 6 canadas (8,4 litros no sistema métrico decimal), ou seja, o equivalente a um alqueire de azeite.
} 
a Câmara de Lisboa proibiu que, daí para diante, se continuasse a exigir aos donos da azeitona este azeite, a tal título ${ }^{118}$.

Esta disposição, com a qual se pretendia estabelecer uma certa uniformidade nas compensações a cobrar por cada moedura de azeitona, deixou, entretanto, de ser respeitada no termo de Lisboa. Devido ao aumento do salário dos lagareiros, bem como das despesas com as cavalgaduras, seiras e outras alfaias e produtos necessários à laboração dos lagares, entretanto verificado (segunda metade do século XVII), os senhorios deixaram de poder respeitar a tabela fixada em 1575 , passando a cobrar outros valores. Daí a necessidade de o senado da Câmara voltar a legislar sobre este assunto. Num outro regimento (ou aditamento ao de 1572), sem data, de que já falámos várias vezes, ordenou que, "no dito termo, levem todos os lagares a mesma moagem e machia e em concideração dos gastos que hoje nelles se fazem per cada moedura pagara o dono da azeitona hum tostão, alem da machia que he de des hum e não pagarão cevada pera besta, azeite pera cabaço, nem outro algum emolumento"119. As autoridades municipais apenas mexeram nas quantias exigidas pela moagem da azeitona, que subiram dos 50 e 60 réis fixados em 1575 para um tostão, ou seja, para o equivalente a 100 réis, o que representa uma subida da ordem dos 50 e $40 \%$. A lagaragem de dez/um manteve-se.

Voltando às adições de 1575 , no que respeita ao direito dos senhorios e donos da azeitona ao bagaço, o senado da Câmara de Lisboa limitou-se a sancionar o que, até então, havia sido "acustumado", e que era dar "tres cestos de cada moedura ao dono d'azeytona e ficar pera o dono do laguar o resto", provavelmente para que este o utilizasse como combustível para a fornalha ${ }^{120}$.

${ }^{118}$ Em Coimbra, onde todos os lagares existentes em 1554 eram de calda ou água, levava-se por cada moedura de azeitona, além da décima parte do azeite de maquia, oito réis, "sem mais outro comer, nem beber, nem lenha, nem outra $\mathrm{n}[$ en] hũa coussa, somente os dittos hoito reis secos, [...]" (LC, 1, Regimento dos lagares d'azeyte, caps 9, 17 e 27 / J. Pinto Loureiro, ob cit., pp. 5 e $7-10)$.

${ }^{119}$ Regimento de lagar de azeite, cap. 10 (Artur Salvado, ob. cit., p. 55).

${ }^{120}$ Adições de 1575, cap. 10 (Ap. Doc., pp. 315-316). Em Coimbra, verificou-se alguma hesitação da parte das autoridades da cidade, no tocante ao direito dos donos da azeitona e senhorios dos lagares ao bagaço. No Regimento dos lagares d'azeyte de 1554, diz-se que alguns destes senhorios, a partir de certa altura, passaram a reivindicar para si toda a baganha - que os donos da azeitona costumavam levar, "se a queriam e [dela] aviam mester" -, com o argumento de que, sem ela, não podiam fazer "a tal emnovação", ou seja, transformar os seus lagares, que eram de sertã, em lagares de água ou de calda. Os regedores da cidade, atendendo às despesas que eles, ou os seus rendeiros, faziam não só com a comida e a bebida dos lagareiros, mas também com a lenha para as fornalhas, decidiram que o bagaço fosse repartido a meio com os donos da azeitona, por lhes "parecer cousa justa razoada", ou, se o quisessem queimar nas fornalhas para a feitura do azeite, podiam fazê-lo, 
Neste mesmo artigo, se determinou que os donos (ou os rendeiros) dos lagares dessem de comer aos lagareiros, moedores e acarretadores, o que leva a supor que, até então, os donos da azeitona haviam contribuído com algumas vitualhas para a sua alimentação. Todo aquele que não cumprisse o estipulado neste capítulo ficava sujeito ao pagamento de uma multa no valor de 2000 réis, devendo ainda "restetoir a seus donos d'azeytona o que mais do sobredicto se levar".

\section{Normas relativas à fiscalização dos lagares e penas aplicadas aos que violassem o disposto nas adições de 1575}

Na primeira parte deste trabalho, dissemos que a actividade dos lagareiros e a disciplina nos lagares estavam sob o controlo da Câmara de Lisboa, a qual, para efeito de fiscalização, fazia deslocar até eles os almotacés das execuções. A estes oficiais da justiça competia, igualmente, julgar as infracções cometidas pelos mestres e seus auxiliares no exercício deste mester e aplicar as penas previstas no seu regimento. Nas suas deslocações a estas instalações, para efeito de correição, faziam-se acompanhar, por vezes, dos examinadores dos candidatos a mestres, para que estes os coadjuvassem nas questões de ordem técnica, onde decerto não eram especialistas.

Entre 1572 e 1575, a situação alterou-se, conforme mostra um dos capítulos das adições deste último ano, onde se manda os juizes dos limites, acompanhados dos respectivos escrivães, "cada oyto dias, correr os laguares e vegiar se acham nelles allgũa cousa $[\mathrm{mal}]$ feyta, e enfformar-se se se faz comtra o regimento,

devendo o restante ser repartido entre eles em igual proporção. Os fregueses de fora da cidade tinham direito a toda a baganha da sua azeitona, ou à parte que dela sobejasse da feitura do azeite. Devido a esta sua decisão, os senhorios passaram a alimentar as fornalhas dos seus lagares com a baganha da azeitona, a fim de evitarem as despesas com a lenha, que as autoridades da cidade haviam feito recair sobre eles. Privados do bagaço, ou de grande parte dele, os donos da azeitona protestaram, com o argumento, supomos, de que o "fogo [por ele alimentado] nam era tão forte pera que as agoas fervesem e tomasem aquela quemtura que cumpre e hee necesario pera os azeites poderem ser bem escousados e naquela perfeyção que compre e se sempre fez, por sempre se as agoas aquemtarem com lenha e nam com baguanha [...]". Sensíveis a este argumento, os regedores acordaram-se que, "daqui em diamte, em ne $[n]$ hum lagar d'aguoa, nom aquemtem a aguoa pera as caldas que se dão aos azeites senam com lenha, e não com baguanha, assy e na maneira e como se sempre fazya quamdo os donnos dos azeites davam a lenha. E somente poderam acemder o fogo com as ditas baganhas, como isso mesmo se soya de fazer. Porem, os dittos senhorios averam mettade das dittas baganhas [...] e o povo e donno dos azeites a outra mettade [...]" (caps 33 e 34 / J. Pinto Loureiro, ob cit., pp. 12 e 13). Como não temos mais notícias sobre este assunto, somos levados a supor que seria este o destino do bagaço da azeitona moída por volta de 1575, nos lagares de Coimbra. 
e fazer disso auto e o trarão a Camara dentro em tres dias, sob a dita pena [de dous mill reis da cadea]"121. De acordo com o conteúdo deste capítulo, a fiscalização dos lagares de azeite parece ter deixado de ser (no todo ou em parte) da responsabilidade directa dos almotacés das execuções, pelo menos no que diz respeito aos lagares do termo de Lisboa, para passar para a alçada dos juizes dos limites $^{122}$. O julgamento das infracções detectadas, bem como a aplicação das respectivas penas, parece ter continuado a ser da competência daqueles magistrados, uma vez que as adições de 1575 nada dizem em contrário.

Quanto ao motivo da alteração verificada, não sabemos precisar, mas é provável que se tivesse prendido com o facto de as visitas dos almotacés das execuções aos lagares serem demasiado espaçadas no tempo e irregulares e, por conseguinte, insuficientes para impedir as irregularidades entretanto detectadas. Exigir da parte destes magistrados municipais um maior esforço na fiscalização desta actividade, esforço esse que passava pelo aumento das suas visitas a estas instalações, talvez não fosse possível, atendendo às inúmeras questões que tinham decerto de resolver no seu dia-a-dia, relacionadas com os oficiais mecânicos. A alternativa de fazer recair esta correição sobre os juízes ou vedores dos lagareiros, à semelhança do que se passava na quase totalidade das outras profissões arregimentadas, cuja actividade estava sob o controlo dos próprios juízes ou vedores, também não era possível, porque, no seu caso, não existiam tais "magistrados", nem o escrivão para os acompanhar nas suas visitas aos lagares, com a missão de escrever os autos ${ }^{123}$.

${ }^{121}$ Adições de 1575, cap. 9 (Ap. Doc., p. 315).

${ }^{122}$ Pouco sabemos acerca dos juízes dos limites (aportelados?), embora admitamos tratar-se de juízes locais, eleitos pelo povo ou nomeados pelas autoridades camarárias, para as coadjuvar no exercício das suas funções, atendendo ao facto de o concelho de Lisboa ser demasiado extenso e populoso. É provável que se identifiquem com os juizes do lugar, que aparecem referenciados no Regimento dos lagareiros de vinho de 1572 (LROM, cap. LXXVIIII / Vergílio Correia, ob. cit., p. 231).

${ }^{123} \mathrm{De}$ acordo com uma postura camarária em vigor nesta altura, foi "acordado que todos os Juizes, ou veedores dos officiaes mecanicos, seião obrigados $[a]$ visitar as tendas de seus officiaes e fazer correição com o escrivão de seu cargo de trinta em trinta dias, ou de quinze em quinze, se per seu regimento o tiuerem assi ordenado, e cada uez que necessario for. E as obras que acharem que não são feitas como devem, as trarão aa Camara ou as leuarão aos almotacees das execuções, para se fazer nellas execução conforme aas posturas da cidade. E todas as vezes que a dita diligencia fezerem, virão a esta Camara dar conta de como a fezerão e do que acharem, para se saber o que nisso fazem. E quando não poderem vir aa Camara, o irão fazer saber ao vereador das execuções que tem o pelouro dellas. E os que assi não fezerem pagarão do tronco dez cruzados [...]" (LROM, Livro segvndo de posturas geraes para os officiaes mecanicos, cap. II - Que os Juizes dos officios mecanicos visitem as tendas dos officiaes / Dr. Vergílio Correia, ob. cit., pp. 233-234). 
$\mathrm{Na}$ falta de autoridades privativas neste ofício, sobre as quais pudesse recair a fiscalização dos lagares, e perante a impossibilidade de os almotacés reforçarem a sua vigilância pessoal, recorreu-se aos juizes dos limites como seus auxiliares no desempenho desta função. Na verdade, só assim se compreende o porquê de, num outro regimento de lagar de azeite, posterior ao de 1572, se ordenar aos almotacés das execuções que, nas suas visitas a estas instalações, verificassem se as medidas do azeite haviam sido aferidas nesse ano e se o pote de medir este mesmo óleo tinha " algum buraco, e por dentro, algum pedaço de casca de coco, ou cortissa, que fassa enchimento para levar menos azeite [...]". Isto significa que, ao tempo da sua promulgação (século XVII), continuava a recair sobre estes oficiais municipais a responsabilidade da fiscalização dos lagares de azeite, não obstante o aparecimento de zeladores, entretanto verificado. É provável que estes zeladores, a quem cabia parte do produto das multas que recaíam sobre os lagareiros que haviam violado as normas deste ofício, se identificassem, a nível local, com os juízes dos limites, a que as adições de 1575 fazem referência ${ }^{124}$.

Quanto às penalizações que recaíam sobre os lagareiros que, porventura, infringissem o preceituado nas adições de 1575, estas podiam envolver uma indemnização aos donos da azeitona, caso estes tivessem sido prejudicados com a sua actuação; a privação da liberdade que, no único caso em que esta pena aparece explicitada, é quinze dias de cadeia ${ }^{125}$; ainda, o pagamento de uma pena pecuniária, uniformemente taxada em 2000 réis. Este valor é o mesmo que o Regimento de 1572 havia fixado para a violação de qualquer uma das suas normas. Relativamente ao destino do dinheiro das multas arrecadado pela Câmara de Lisboa, nada se diz, o que leva a supor que continuasse a ser o mesmo que o Regimento dos lagareiros de 1572 indica, ou seja, aplicar-se-ia, no todo ou em parte, nas obras da cidade.

\section{Conclusão}

Em conclusão: a indústria oleícola de Lisboa, depois da reforma e compilação dos regimentos dos ofícios mecânicos, levada a cabo por Duarte Nunes de Lião, passou a estar sujeita à disciplina de um regimento, ou de um novo regimento. Anteriormente a esta sua reforma, pouco sabemos acerca deste ofício - em particular, se se regia por leis privativas, aplicadas por autoridades próprias, sob o controlo das autoridades municipais. A existência de um regimento

\footnotetext{
${ }^{124}$ Regimento de lagar de azeite, cap. 9 (publ. Artur Salvado, ob. cit., pp. 52-53).

${ }^{125}$ Cap. 1 (Ap. Doc., p. 313).
} 
pré-lionino dos lagareiros dos lagares de azeite de Lisboa e termo não é conhecida, o que não significa que não tenha existido. A atribuição de um novo regimento a este ofício pode ter levado à destruição do exemplar antigo e das respectivas cópias, uma vez que a sua validade havia expirado. Se existiu, o que não é líquido, as suas disposições devem ter deixado, entretanto, de ser respeitadas, como aconteceu noutros $\operatorname{casos}^{126}$.

O Regimento dos lagareiros dos lagares de azeite de Lisboa de 1572 compunha-se,conforme vimos ao longo do desenvolvimento deste nosso trabalho, de um conjunto de disposições reguladoras desta actividade, à semelhança do que se verificava nos outros regimentos lioninos. A distingui-lo destes estava, para além das questões de ordem técnica e normativa específicas de cada ofício, também o facto de nele não haver qualquer indício da existência de autoridades próprias, eleitas pelos mestres lagareiros. A maior parte dos regimentos lioninos começa por aludir à reunião da assembleia anual do ofício, a realizar normalmente no mês de Janeiro, com a finalidade de nela se elegerem dois juízes e um escrivão, de entre os oficiais presentes ${ }^{127}$. Aos juízes eleitos competia, entre outras funções, examinar os candidatos a mestres e "visitar" as tendas dos oficiais acompanhados do escrivão, a fim de verificarem se os produtos ou as obras nelas manufacturados estavam de acordo com as exigências do seu regimento. No caso de detectarem irregularidades, as obras contrafeitas (danadas) seriam por eles confiscadas e enviadas à Câmara ou aos almotacés das execuções, para que estes ou os vereadores municipais as examinassem e punissem os infractores, de acordo com a gravidade do delito cometido.

No Regimento dos lagareiros dos lagares de azeite não há qualquer referência à realização desta assembleia, tudo apontando para a inexistência dos dois juízes e do escrivão neste ofício: é o caso do exame dos candidatos a mestres ser feito por dois examinadores escolhidos pela Câmara, quando, nos outros mesteres, era da competência dos respectivos juízes; a certidão do exame de mestria dos candidatos a mestres era passada por um escrivão oficial da Câmara e não pelo escrivão da profissão; por outro lado, a fiscalização dos lagares não estava a cargo dos respectivos juízes, mas sim dos almotacés das execuções, coadjuvados, no ponto de vista técnico, pelos examinadores dos candidatos a mestres e, por volta de 1575, também pelos juízes dos limites. Se existissem tais

${ }^{126}$ Sobre este assunto, vide o extracto da acta da sessão da Câmara de Lisboa de 24 de Janeiro de 1572, que apresentámos na p. 269, nota 10.

${ }^{127} \mathrm{Em}$ geral, os ofícios tinham dois juízes e um escrivão, mas podiam ter outras autoridades profissionais além destas. O número de juízes também podia variar de acordo com a importância do ofício (vide Livro dos Regimentos dos officiaes mecanicos ). 
autoridades eleitas pelos lagareiros, decerto que as funções indicadas seriam também elas da sua competência. A falta destas, sobretudo dos dois juízes, fazia com que o ofício de lagareiro estivesse directamente dependente das autoridades camarárias ou, mais concretamente, dos almotacés das execuções. A esfera de competências dos dois examinadores dos candidatos a mestres, eleitos pela Câmara de entre os oficiais lagareiros, não ia além das questões de ordem técnica. No resto, tudo parece depender da vontade das autoridades camarárias, e também dos donos da azeitona, que a elas faziam chegar as suas queixas ou reivindicações.

Na sessão da Câmara do dia 17 de Outubro de 1575, na qual estiveram presentes o seu presidente, vereadores e demais oficiais com assento no Senado ${ }^{128}$, foi "revisto o Regimento dos laguares e os apomtamentos que se mandarão fazer aos juizes dos lymytes com pareser do povo [donos da azeitona ?] e examinadas as rezois e remedios que se derão pera se tirar quoanto pareceo sofrivel as ocasyois de se furtar o azeite e pera se milhor beneficiar e segurar". De acordo com esta passagem das adições de 1575, os mestres lagareiros não devem ter sido ouvidos pelo Senado sobre as matérias em questão e, como não tinham representação na Casa dos Vinte e Quatro, é provável que os procuradores desta Junta, presentes nesta sessão, não se tivessem empenhado grandemente na defesa dos seus interesses e/ou da sua reputação, conforme podemos concluir da leitura dos capítulos nela aprovados e que foram adicionados ao Regimento de 1572.

A ausência das referidas autoridades neste mester é, até certo ponto, compreensível, na medida em que estamos perante um ofício cuja laboração, em anos normais de azeitona, não devia ir além, ou muito além, de três ou quatro meses ${ }^{129}$. Isto significa que os mestres e o restante pessoal dos lagares, nos outros meses do ano, se dedicavam a outros trabalhos, nomeadamente na agricultura. A afinidade existente entre ambas as actividades, bem como o facto de o trabalho dos lagares ser melhor remunerado que o agrícola, deviam levar muitos rurais a fazerem-se lagareiros no tempo da safra da azeitona, a fim de melhorarem os seus orçamentos familiares. Ao carácter temporário desta indústria, juntar-se-ia o facto de alguns mestres serem oriundos das Beiras e de outras partes do território, os quais, uma vez terminada a safra dos lagares,

\footnotetext{
${ }^{128}$ Relativamente aos nomes dos membros que estiveram presentes nesta sessão, vide supra, p. 267 , nota 7 .

${ }^{129} \mathrm{Em}$ Coimbra, em anos de abundância, a moagem da azeitona chegou a prolongar-se até ao mês de Junho, conforme se verificou na safra de 1781 (vide João António Dalla-Bella, ob. cit., pp. 36 e 127, nota 1, e António de Oliveira, ob. cit., vol. I, p. 505, nota 1).
} 
regressariam às suas terras de residência ou naturalidade, desligando-se do vínculo que os havia ligado à indústria oleícola de Lisboa e termo, nesse ano. Atendendo a ambos os factos, a existência de autoridades próprias, num ofício com tais características, não parecia, na verdade, justificar-se.

Em suma, os trabalhadores da indústria oleícola de Lisboa, por volta de 1575, estavam sujeitos à disciplina de um regimento, cujo cumprimento estava sob o controle das autoridades camarárias. Era uma categoria de mesteirais desprovida de quaisquer poderes reivindicativos ou liberdade de actuação, e já nesta altura estigmatizada pela suspeição de os seus elementos desviarem azeitona/azeite do povo, a quem pertencia a matéria-prima que trabalhavam: "Quem o azeite mede, as mãos unta", dizia uma velha máxima aplicada aos medidores de azeite, na qual os lagareiros estavam englobados. Para acabar com o espírito de fraude, que parecia ter-se instalado nesta indústria, foram tomadas várias medidas pelo senado da Câmara, de que demos conta ao longo do desenvolvimento deste nosso trabalho. 


\section{Apêndice Documental}

1575 NOVEMBRO 10, Lisboa-Cópia do Regimento dos lagareiros dos lagares de azeite de Lisboa de $1572^{130}$ com os artigos que se lhe acrescentaram em 1575, mandada tirar para o lagar de Maria Monteiro.

IAN/TT-Mosteiro de S. Vicente de Fora, $2^{\mathrm{a}}$ incorporação, cx. 9, L - $1746^{131}$

Regimento dos laguareiros e donos ${ }^{132}$ dos laguares [de azeite $]^{133}$

Prymeiramente, em cada hum anno amte que venha o tempo de os laguares fazeren, se ellegerão pella Camara dois officiais laguareiros boons omeis e sufficiemtes em seu officio pera examinadores dos que novamente quyserem tomar carguo dos laguares e serem mestres delles, e pera os vesytarem e verem a obra que se nelles faz. Aos quoais sera dado juramento dos Santos Evangelhos [em Camara $]^{134}$ que bem e verdadeyramente examynem os ditos mestres e visitem os laguares.

${ }^{130}$ Publ. Esteves Pereira e Guilherme Rodrigues, ob. cit., vol. IV, s. v., "lagareiro", com modernização ortográfica e algumas leves alterações; Vergílio Correia, Livro dos Regimẽtos dos Officiaes mecanicos [...], pp. 181-186; F.-P. Langhans, Apontamentos para a história do azeite em Portugal, entre as pp. 94-103, em fac-simile, e por Artur Salvado, em Alguns apontamentos para o estudo evolutivo da indústria oleícola portuguesa, pp. 33-43, com leitura em ortografia modernizada, acompanhada da respectiva reprodução em fac-simile.

${ }^{131} \mathrm{Na}$ transcrição desta fonte, adoptámos o seguinte critério: desdobrámos as palavras abreviadas e actualizámos as maiúsculas e as minúsculas; colocámos as letras, sílabas e palavras acrescentadas em itálico e dentro de parênteses rectos, e passámos o $j$ longo a breve; simplificámos as consoantes duplas usadas no início das palavras e respeitámos as variantes de um mesmo termo; substituímos o til das abreviaturas por um $m$ ou $n$, quando a sua função era a de nasalar e a pronúncia das palavras, com ele grafadas, correspondia à actual; e mantivemo-lo nos casos em que ela se alterou; separámos as proclíticas das respectivas palavras aglutinadas por um apóstrofo e unimos os pronomes às formas verbais que os precediam por um hífen; actualizámos o uso da cedilha e introduzimos alguns sinais de pontuação, sobretudo vírgulas, a fim de tornar o texto mais inteligível; reintroduzimos a numeração nos capítulos do regimento de 1572, que o escrivão da Câmara havia suprimido ao copiá-los, entre parênteses rectos, e numerámos de igual forma os capítulos das adições de 1575; passámos os números romanos, grafados em minúsculas, para maiúsculas, e indicámos as mudanças de fólio no corpo do documento, entre parênteses rectos.

${ }^{132}$ A expressão "e donos" não consta no documento original. Por serem muitas as variantes ortográficas verificadas entre o original e esta cópia, optámos por indicar apenas as supressões e os acrescentos apurados.

${ }^{133}$ Texto do original não copiado pelo escrivão da Câmara.

${ }^{134}$ Vide nota anterior. 
[1.-] E quoamdo allgum novamente vier pedir carta pera mestre de laguar ao escryvão da camara, trara certydão dos ditos examynadores feyta per huum escryvão oficial da camara e asynada per elles, de como he abil e sufficiemte pera o dito oficio. E o exame que lhe farão sera por pratiqua, fazemdo-lhe as pergumtas que lhe bem pareceren per que posão comprender sua sofficiemcia. E achando que he abil e sufficiemte lhe sera dada sua carta na forma acustumada e avera juramento em camara e dara sua fiamça como dão os outros [fl. 1v] officiais que recebem do alheio e os fiadores que derem não serão os mesmos donos dos laguares, sendo pesoas nobres e poderossas, mas tais per que se bem possa aver aquyllo por que os laguareiros forem obriguados. E quoallquer laguareiro que sem ho dito exame, juramento, fiança e carta da camara trabalhar em allguum laguar desta cidade e seu termo do tronquo omde estara quymze dias paguara dous mill reis, a metade pera a cidade e a outra pera quem o acusar. E per ho dito exame paguara cada laguareyro que se examinar vynte reis a cada huum dos ditos examinadores.

[2.- ] E os ditos examinadores serão obryguados de yrem com cada huum dos allmotacees das execuçoes todas as vezes que requerydos forem a visitar os laguares desta cidade e seu termo e verem a obra que se nelles faz pera que, achando que a fazem como não devem, fação os ditos allmotacees aos dito $[s]$ laguareiros paguar todo ho dano e perda aos donos do azeite e os comdenem na mais pena que segundo suas [fl. 2] cullpas merecerem. E pello trabalho que na dita vesitação levarem e pellos dias que nisso guastarem lhes mandara dar ho allmotace a custa do rendeiro do termo o que lhe parecer justo.

[3.-] E mandão que tanto que hum laguareyro emtrar em quoallquer laguar des que começar a çaffra ate acabar e sarar o laguar não durma noite allgũa fora delle por os roubos que se fazem e periguos que em sua absencia podem acomtecer. E o que o comtrario fizer do tronquo paguara dous mil reis, a metade pera as obras da cidade e a outra pera quem o acusar.

[4.- ] Item, nenhuum laguareiro estara em laguar omde parente seu amdar por moedor ou acaretador por evitar os furtos que huns a outros comsintem, sendo parentes ou dividos. E fazendo ho comtrario cada huum delles do tronquo paguara dous mill reis a metade pera a cidade e a outra pera quem o acusar.

[5.-] Item, nenhuum laguareiro sera ousado a vender azeite allguum nos laguares [fl. 2v] em que estyver por laguareiro, nem recebera pera isso dinheiro de parte allgũa e seus donos soomente o poderão vender quoando quyserem. E isto sob a dita pena. 
[6.-] Item, nenhuum laguareiro comsentira no laguar em que estyver enquoanto lavrar molher allgũa sallvo sendo dona d'azeitona ou molher que compra azeites e com seus donos o for receber nem outrosy aguasalhara pesoa allgũa outra pera dormir de noite no dito laguar sallvo as pesoas que são ordenadas pera serviço delle. E se ho dono do laguar lhe mandar o comtrario, o fara saber a camara pera se fazer o que for justiça. E o que o comtrario fezer paguara a sobredita pena.

[7.-] Item, nenhuum laguareiro, moedor e caretador serão ousados no laguar em que estyverem lavrar azeitona sua, sob pena de dous mill reis do tronquo.

[8.- ] Item, nenhuum laguareiro consentira que se faça de comer, asy asado como cozido ou de quoallquer maneira que seja, a boca da fornalha, sallvo o que elle e as pesoas que servem no laguar ouverem de [fl. 3] comer, nem isso mesmo consentira que se fação tibornas sallvo os donos dos azeytes e de seus propryos azeytes pera sy e pera os officiais do laguar. E a outra pesoa allgũa não comsentira fazer tal nos ditos laguares não tendo nelles azeitona. $\mathrm{E}$ o que o comtrario fizer paguara a sobredita pena. E se ho dono do laguar constranger que se faça o contrario o vira dizer nesta camara pera prouver nisso como for justiça.

\section{Pera os donos dos laguares}

[9.-- Em todo $[o]^{135}$ laguar d'azeite avera tulhas bem repartydas, em que se bem posão recolher cimquoenta moeduras de azeytona que se podem fazer em huum mes e o mestre do laguar sera avisado que faça prymeiro $[a]^{136}$ azeitona que prymeiro vier ao laguar, sallvo se ho dono da dita azeytona que prymeiro a trouxe der luguar a outro pera que $\mathrm{se}^{137}$ faça prymeiro que a sua.

[10.- ] E o dono da azeitona a medira ou mandara medir ${ }^{138}$ no laguar per pesoa sua de que se comffie. E não [fl. 3v] a querendo elle medir então a medira o acaretador por ter juramento pera isso e sem ser medida não sera moida pera cada hum saber o que lhe fumde a sua azeytona. E o mestre que ho comtrario fizer paguara do tronquo dous mill reis, a metade pera a cidade e a outra pera quem o acusar.

${ }^{135}$ Artigo não copiado do original pelo escrivão.

${ }^{136}$ Vide nota anterior.

${ }^{137}$ No original: "a", em lugar desta partícula apassivante.

${ }^{138}$ Segue-se uma mancha de tinta, que nos pareceu ter sido feita intencionalmente pelo escrivão, com a finalidade de encobrir uma palavra (ou parte dela) indevidamente escrita. 
[11.- ] E em cada laguar avera duas meyas fanguas affilladas pello afillador da cidade que serão de ${ }^{139}$ rasoura. A quoall medida de ${ }^{140}$ rasoura sera avellada e não callcada. E os acaretadores dos laguares e moedores que per outras medidas medirem a dita azeytona senão pellas ditas meias fanguas rasouras ou medirem per cestos ainda que per elles seu dono da azeytona lh'a queyra dar paguarão pella prymeira vez que nisso forem comprendidos cada huum dous mill reis e pella segunda averão a dita pena em dobro a metade pera as obras da cidade e a outra pera quem o acusar. E hũa das ditas meas famguas estara comtinuadamente nas tulhas que se acaretarem pera por ella se medir [fl. 4] [a $]^{141}$ azeytona quoando se houver de moer e saber se lhe fez verdade o acaretador ou ho dono da azeytona se ha mandar medir. A quoall medira o dito moedor peramte o laguareiro pera, per seu juramento, serem cridos aserqua do erro da medida d'azeytona que se lhe fizer nas tulhas.

[12.- ] E em cada hum dos ditos laguares avera camtaro allqueyre canada meia canada quoartilho meio quoartilho affillado tudo pello afillador da cidade. E o dono do laguar que cada hũa das sobreditas medidas não tyver do tronquo paguara dous mill reis, a metade pera $\mathrm{a}[\mathrm{s} \text { obras } d a]^{142}$ cidade e a outra pera quem o acusar.

[13.- E em todo $[o]^{143}$ laguar avera tamtos potes em que bem posão aguasalhar huum quoarto d'azeite cru, que rezoadamente se pode fazer entre dia e noite sob a dita pena ${ }^{144}$ que paguara o dono do laguar.

14.-] Item, nenhuum dono de laguar trara escravo allguum por moedor nem $^{145}$ acaretador, salvo se ho trouxer pera ajudador do acaretador, porquoanto os sobreditos officiais ham de ter juramento [fl. $4 \mathrm{v}$ ] dado em camara o que se não pode dar a escravos. E o dono do laguar que trouxer escravo por acaretador do tronco paguara dous mill reis a metade pera a cidade e a outra pera quem o acusar.

[15.- ] Item, em cada huum laguar não poderão trazer mais que seys seyras na baguaça e cimquo na fresqua, as quoais serão cada hũa de quoatro pallmos e tres dedos. E as ditas seyras amtes que de casa do esparteyro se levem

\footnotetext{
${ }^{139}$ No original: “da”.

${ }^{140}$ Vide nota anterior.

${ }^{141}$ Vide nota 135.

${ }^{142}$ Vide nota 133.

${ }^{143}$ Vide nota 135.

${ }^{144}$ Esta palavra "pena" não consta do original.

${ }^{145}$ Com o "nem" escrito por cima do primeiro "a" de "acaretador".
} 
pera os laguares serão vistas e medidas pellos juizes do officio dos esparteiros e o laguar em que se não acharem as sobreditas seyras paguara seu dono a sobredita pena.

[16.- ] E este regimento serão obriguados a terem em seus laguares os donos delles em taboas pemdurado pera se poder ver e o lerem todas as pesoas que a elles forem e quoaisquer donos de laguares ou laguareiros que ho dito regimento não tyverem como dito he paguarão cada vez dous mill reis do tronquo a metade pera a $[s \text { obras da cidade }]^{146}$ cidade e a outra pera quem o[ $\left.s\right]^{147}$ acusar. [Fl. 5]

Capitullos que se acrecentarão ao Regimento dos laguareiros

Aos XBII ${ }^{\circ}$ dias do mes de Octubro de $\overline{\mathrm{IB}} .^{\mathrm{c}} \mathrm{LXXB}$, na camara da vereação desta cidade de Lixboa semdo pellos Senhores Presydente, Vereadores e Officiais abaixo asynados revisto o Regimento dos laguares e os apomtamentos que mandarão fazer aos juizes dos lymytes com pareser do povo e examinadas as rezois e remedios que se derão pera se tirar quoanto pareceo sofrivel as ocasyois de se furtar o azeite e pera se milhor beneficiar e segurar.

[1.- ] Prymeiramente que daquy avamte os mestres dos laguares den fiança abonada a todos os danos e perdas e penas dentro do lymite do laguar em que ouverem d'estar e amtes de usaren de seu officio se apressentem com suas cartas e fiamças na camara pera lhes ser dado juramento e serem revistas por huum dos vereadores que se asemtar e lhes pora vista e em cada carta que se pasar e confiança que se der serão decllarada a idade e sinais per que posa ser conhecido e examinado e a fiamça seja de cen mill reis sob a pena do regimento em tall caso que he dous mill reis e quymze dias de cadea. [Fl. 5v]

[2.- ] Item, nenhuum mestre emprestara nem vendera allguum azeyte senão $[o]$ seu dono nem ho medira senão peramte elle nem comsemtira que depois de seu dono vemder ho azeyte o tenha o comprador no laguar senão que ho leve loguo fora peramte ho dito vemdedor ou seu procurador sob pena de dous mill reis paguos do tronquo.

[3.-] Item, não partirão allguum azeite sem ser presemte o dono delle e o senhoryo ou remdeiro do laguar ou seus procuradores sob a dita pena.

\footnotetext{
${ }^{146}$ Vide nota 133.

${ }^{147}$ Acrescento de acordo com o original.
} 


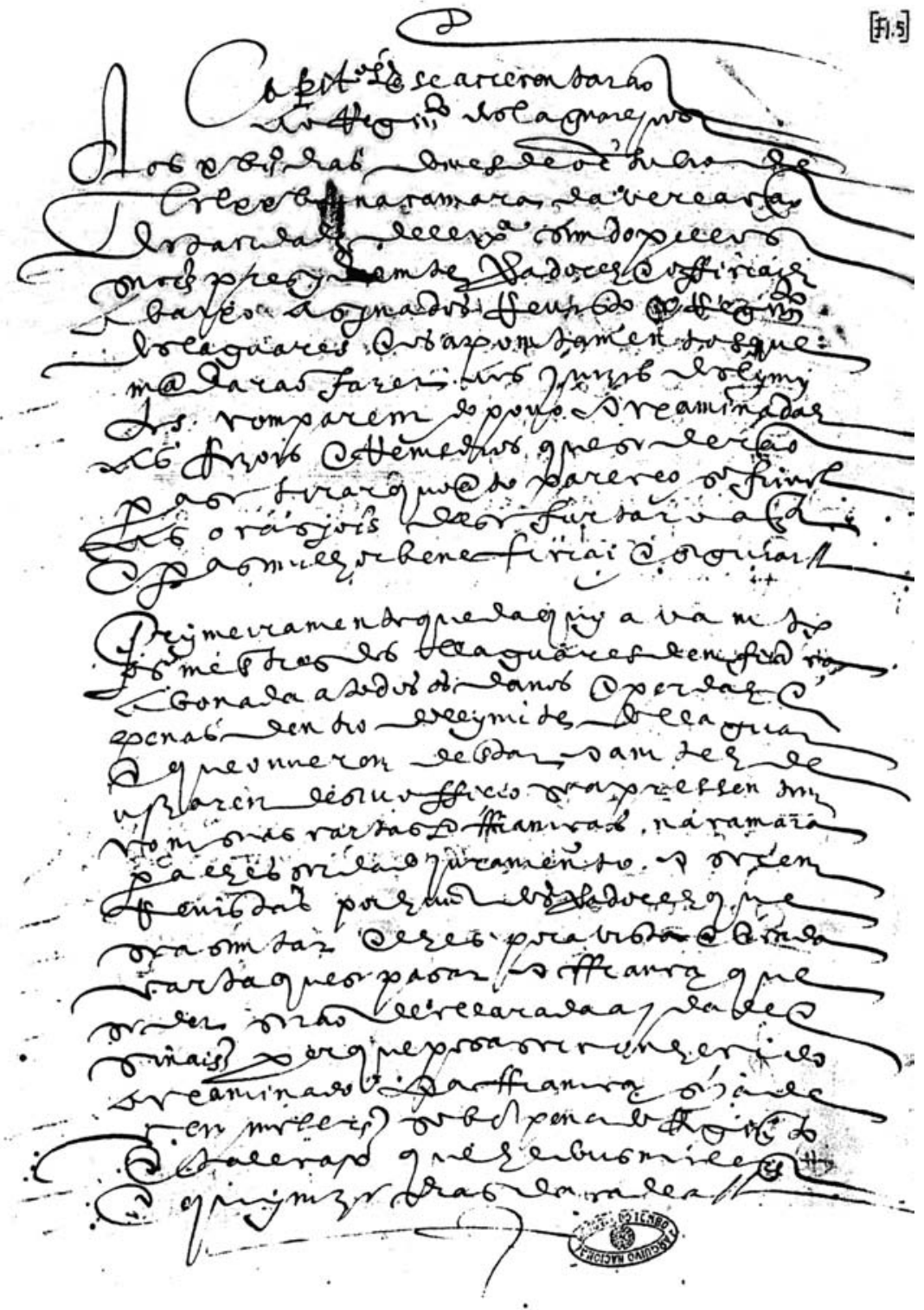

Adições ao Regimento dos lagareiros dos lagares de azeite de 1572, fl. 1, correspondente ao fl. 5 da cópia que publicamos neste apêndice. 
[4.-] Item, não receberão allgũa azeytona no laguar senão depois de não aver outra nas tulhas e não tomara [sic] mais per jumto a outras partes de fora que a que se pode moer dentro em quoatro e quoatro dias por se não estar areffecemdo e guastando e não mesturar hũa com outra ou dar huum azeyte por outro senão comsentyndo-o seus donos d'azeitona que se mesture ou que se tragua prymeiro que seja acabada a que esta no laguar, sob a dita pena de dous mill reis da cadea.

[5.-] Item, não comsentira allguum mestre que este no laguar allgũa vasilha [fl. 6] de comprador de azeite senão ao tenpo que o ouver de comprar nem terão em allgũa vasilha que não seja do senhorio allguum azeite nem emtrevirão em allgũa maneira nas compras delle, sob a dita pena.

[6.-] Item, os donos ou remdeiros dos laguares per sy ou outras pesoas per elles que sejão de boa fama e credito serão obriguados como for soll posto fechar as portas do laguar de fora e abri-las pella menham e não comfiar as chaves dos mestres do laguar nem de outras pesoas que não sejão de comffiamça sob a dita pena.

[7.-] Item, terão muyto cuidado os ditos senhoryos e remdeiros das sartaans que sejão bem vedadas e tenhão suas cobertas de esparto boas com que bem cubrão pera que se não perqua ho azeite e este milhor comservado e mais quente sob a dita pena.

[8.-] Item, os careteyros serão avisados que não acaretem allguum azeite nem meção por cesto senão pella medida de rasoura e não callcarão $[a]$ azeytona com a mão nem com allgũa coussa nem porão a paa com que lanção $[a]$ azeytona sobre a medida ainda que ho dono da [fl. 6v] azeytona nisso comsinta sob a dita pena. E a mesma pena tera ho dono d'azeytona se tall comsentir.

[9.-] Item, os juizes dos lymites com seus escryvãis serão obriguados cada oyto dias $[a]$ correr os laguares e vegiar se acham nelles allgũa cousa [ $\mathrm{mal}]$ feyta e enfformar-se se se faz comtra o regimento e fazer disso auto e o trarão a camara dentro em tres dias sob a dita pena.

[10.-] Item, não levarão mais os senhoryos dos laguares que a dizima do azeite que se nelles fizer, tomando-o do mao e bom e não dos olhos delle e levarão de moer cada moedura sesemta reis nos laguares omde atee guora se não custumou levar menos dinheiro porque honde se custumou atee guora levar a cimquoenta reis não levarão mais. E em nenhũa parte se levara mais allgũa cousa nem a canada e meia canada d'azeyte que se dis do cabaço como a cidade he enfformada que em allgũas partes emdividamente se leva. E os ditos donos 
dos laguares e remdeiros delles serão obriguados a dar de comer aos laguareiros, moedor e acaretador e do [fl. 7] baguaço lhe ficara o acustumado que he dar tres cestos de cada moedura ao dono d'azeytona e ficar pera o dono do laguar o resto do baguaço sob a dita pena e de restetoir a seus donos d'azeytona o que mais do sobredicto se levar.

[11.- ] Item, os mestres dos laguares serão obryguados a moer prymeiro [a] azeytona que prymeiro vier per sua ordem salvo se ho dono da dita azeytona comsentir que se faça a outra que depois vier em luguar da sua sob a dita pena de dous mill reis e da cadea.

[12.-] Item, e este regimento com ho de que atee guora se usou se dara encorporado a cada mestre de laguar o quoall sera obriguado a te-lo pendurado a porta do laguar em parte que fasilmente se posa ver e ler sob pena de dous mil reis e da cadea e de todas as sobreditas penas de hum e outro regimento sera a metade pera a cidade e a outra pera quem o acusar.

Nuno Fernandez de Magalhaes o fes escrever e asinei, oje X de Novembro de İB. ${ }^{\mathrm{c}}$ LXXB annos.

Pagou LXXXI reis.

Nuno Fernandez de Magalhaes

He pera [o] laguar de Maria Monteiro. 
Raguagercofiravea \&a rub.2umale.

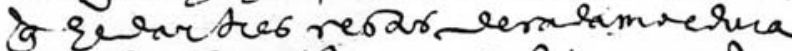

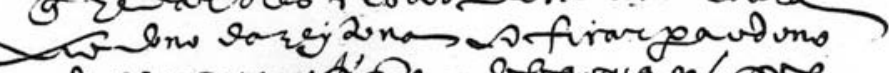

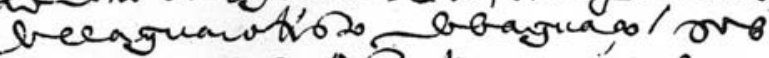
aritapenteve tratopario bur

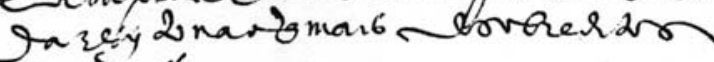
Zenar

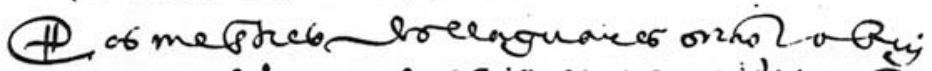

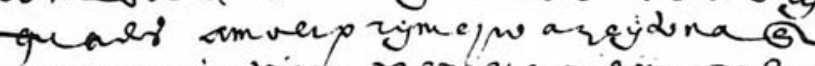

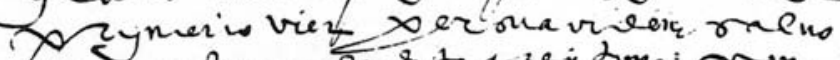

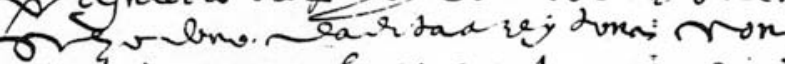

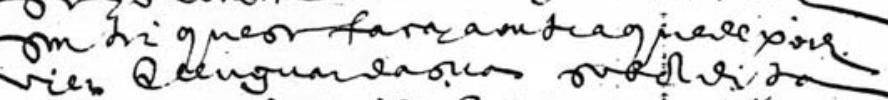

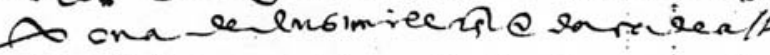

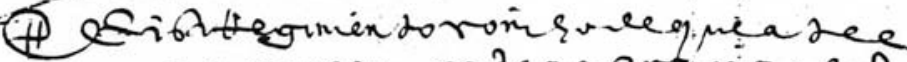
Trumar uprom mara ard pirabd tor yua era decenocn-rutair aporsa erecaguace par dive ffor orifinend

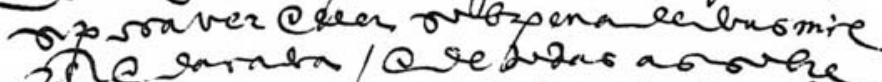

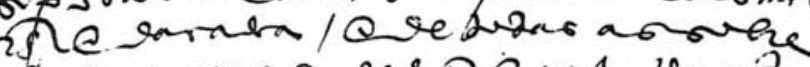

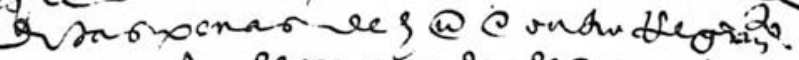

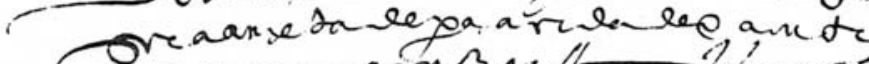

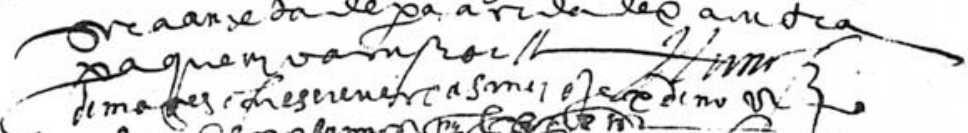

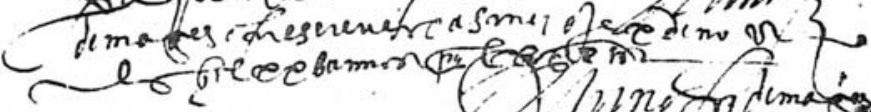
(c)

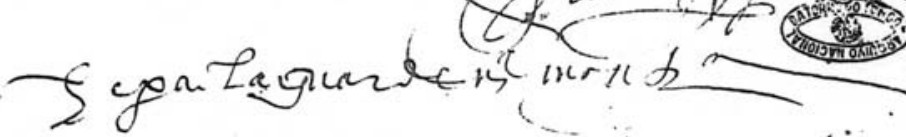
$i^{n}$ 


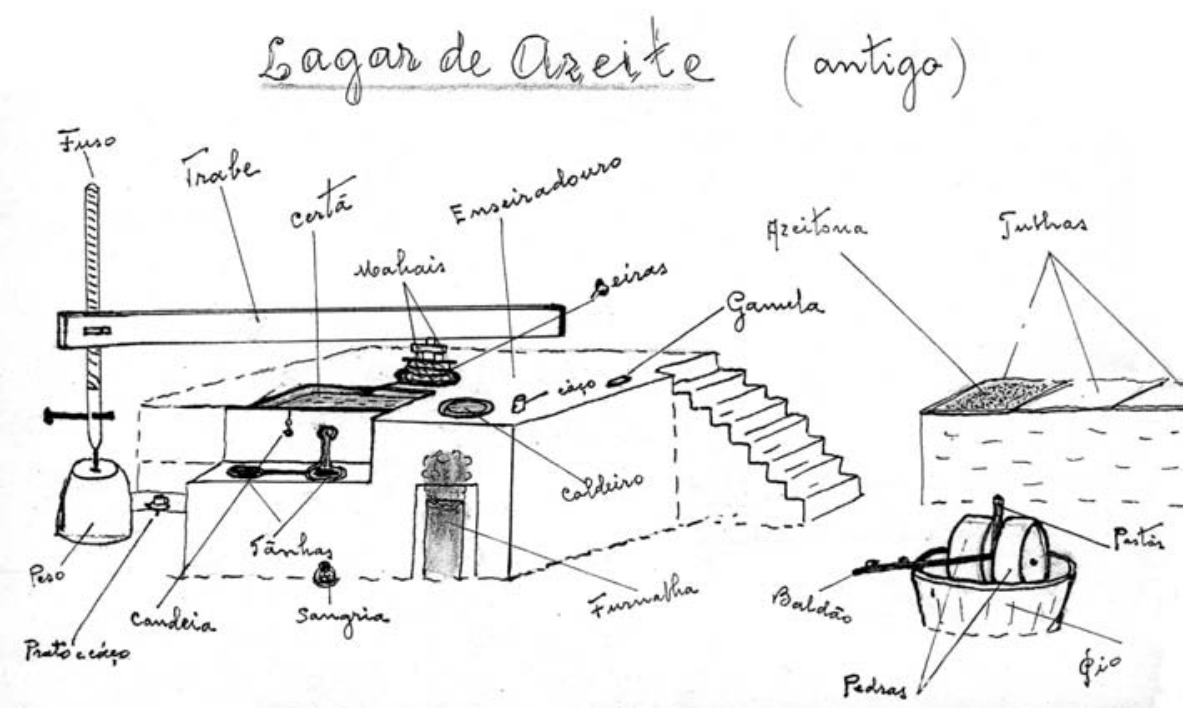

Figura 1 - Desenho de um lagar de azeite, existente em 1942 em Suçães (c. Mirandela, d. Bragança), da autoria do P. Leandro dos Anjos Matos (Inquérito Linguístico Boléo: Suçães, Coimbra, Faculdade de Letras (I.L.L.P.), 1942, entre pp. 86-87.)

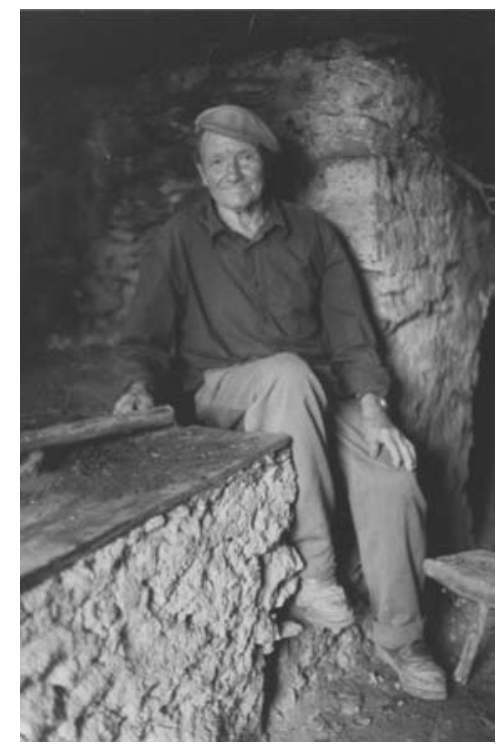

Figura 2 - Foto do antigo mestre lagareiro António Martins, sentado no seu lagar (Ademoço, fr. Cambas, c. Oleiros) 


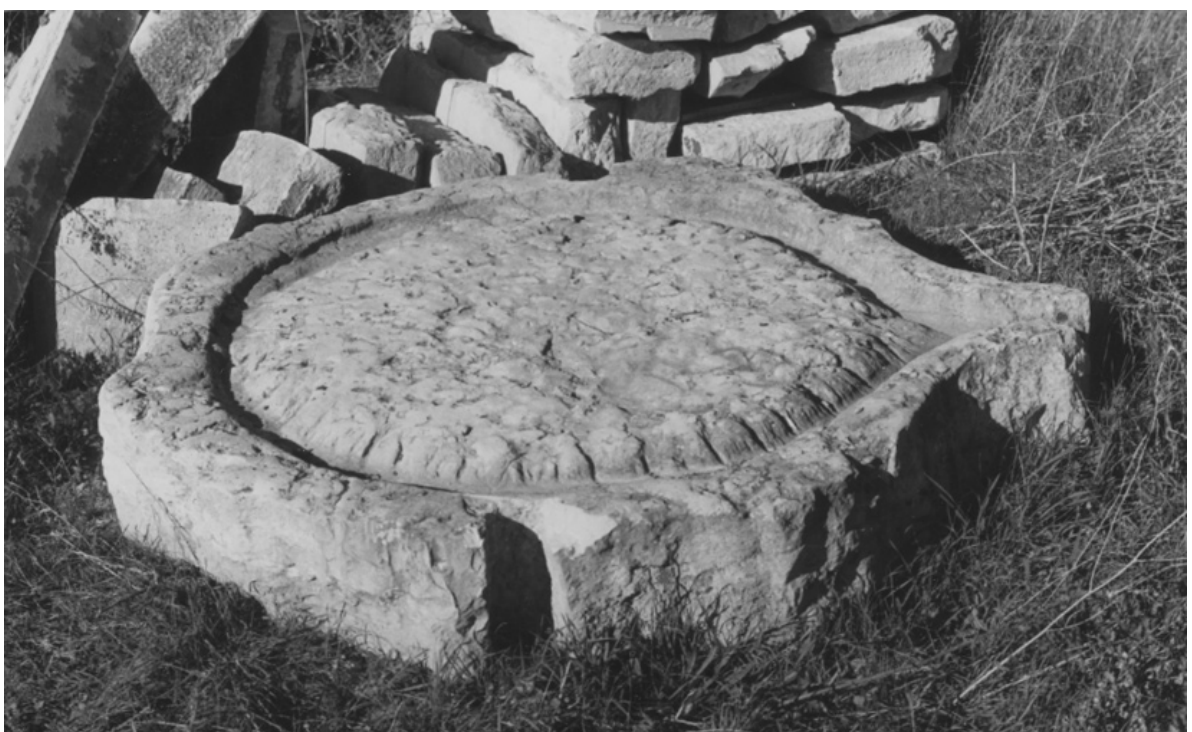

Figura 3 - Alguergue de um antigo lagar de azeite de varas

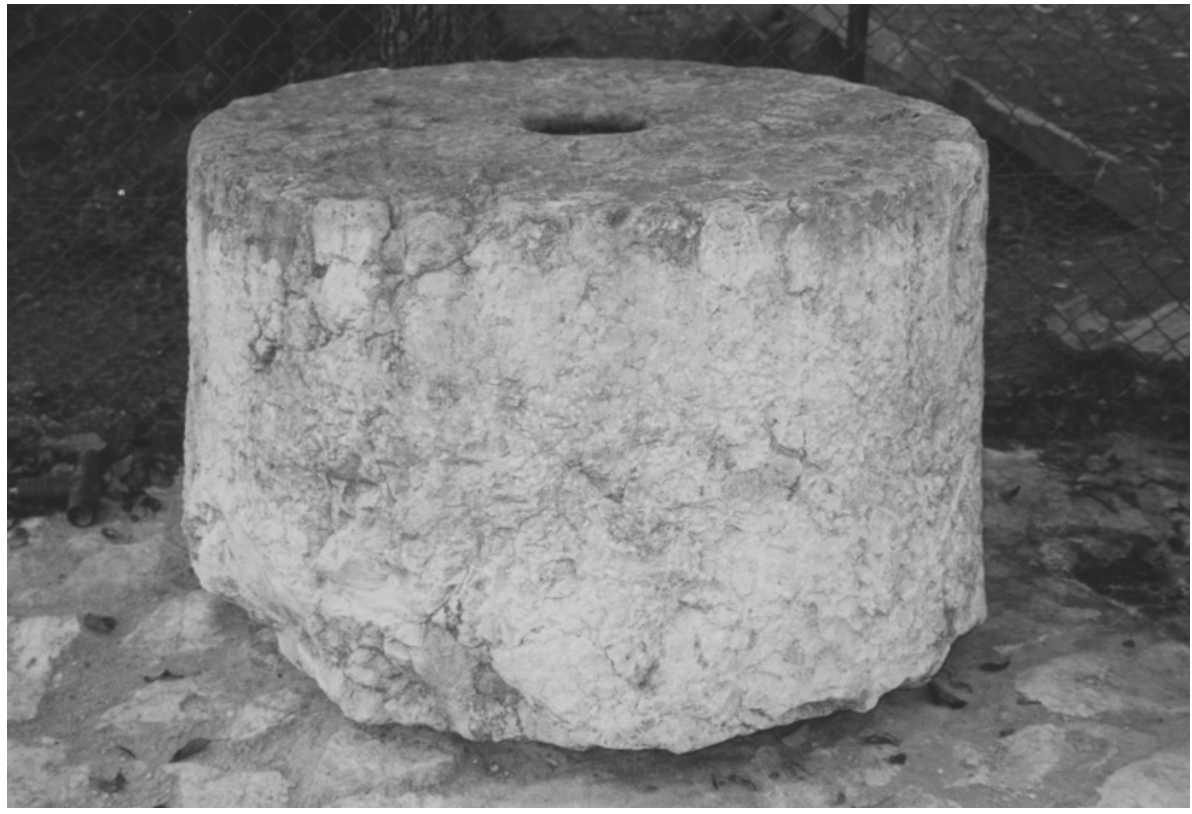

Figura 4 - Peso da prensa de um lagar de azeite de varas 


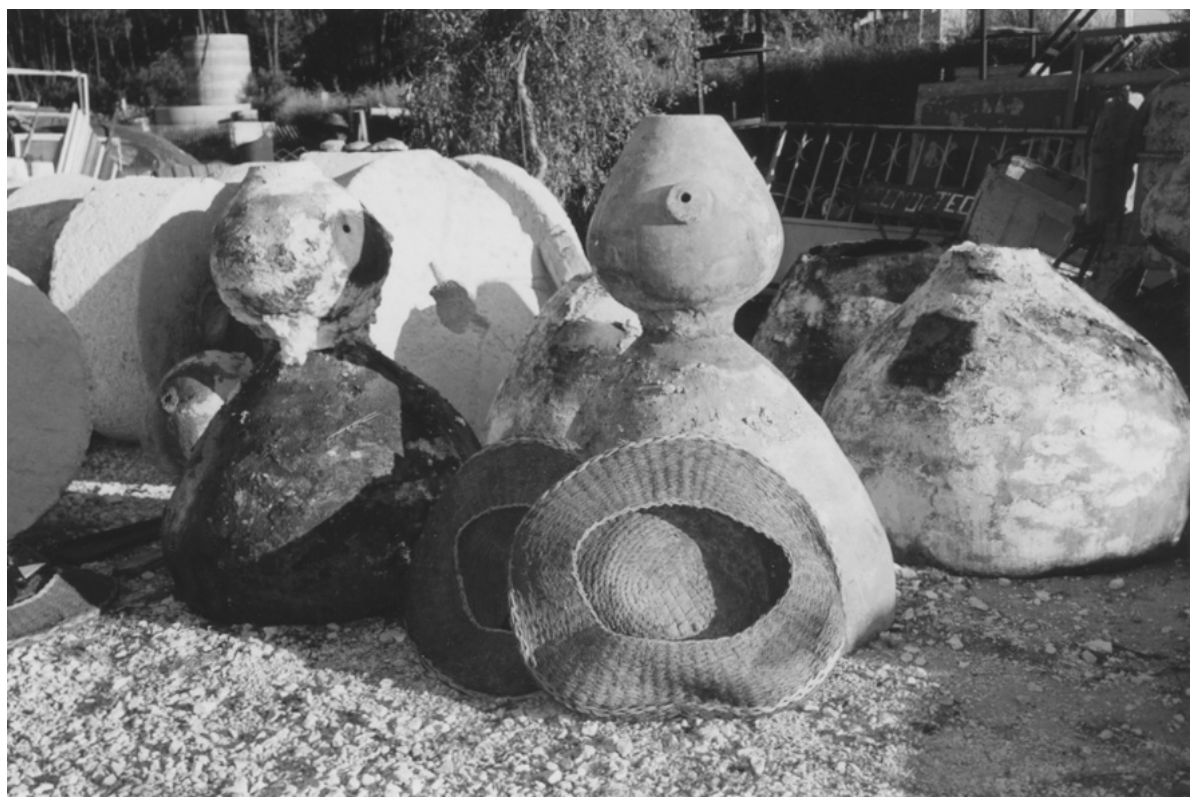

Figura 5 - Seiras de boca larga e tarefas de um antigo lagar de azeite de varas

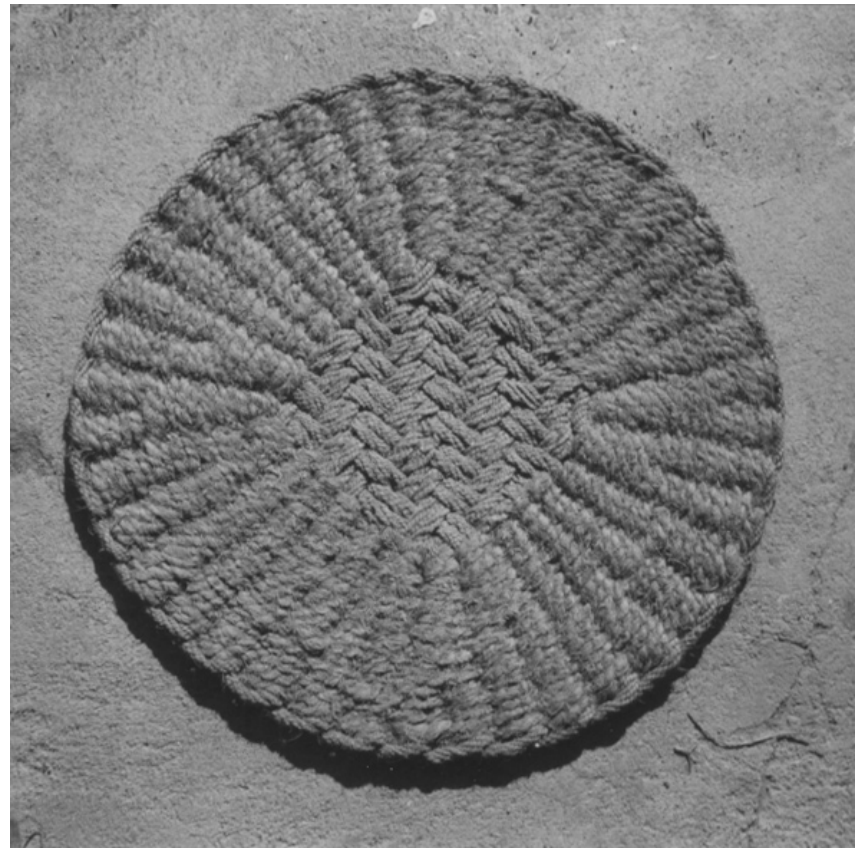

Figura 6 - Capacho usado para tapar a boca das seiras nos antigos lagares de varas 


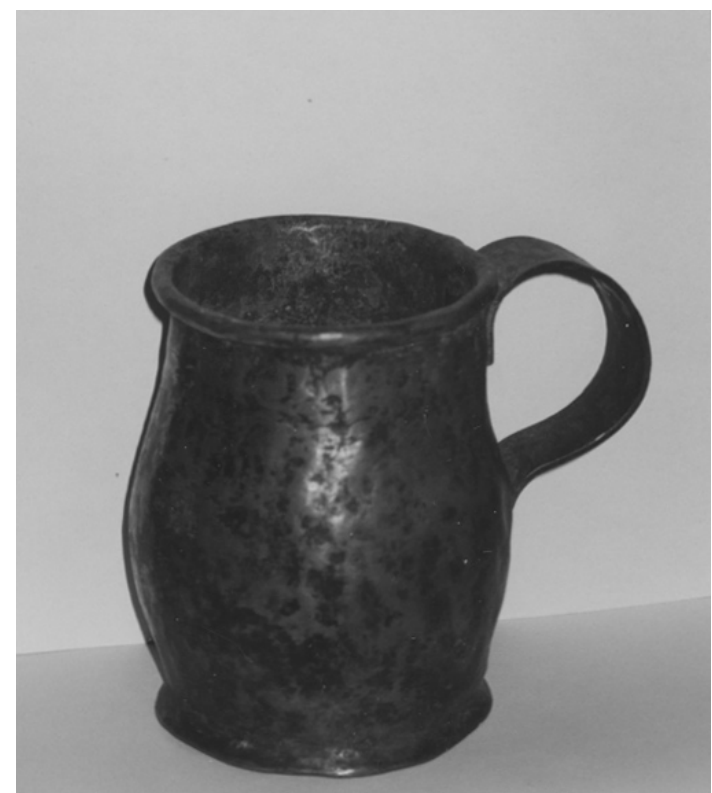

Figura 7 - Antigo caneco de cobre usado para tirar azeite das talhas

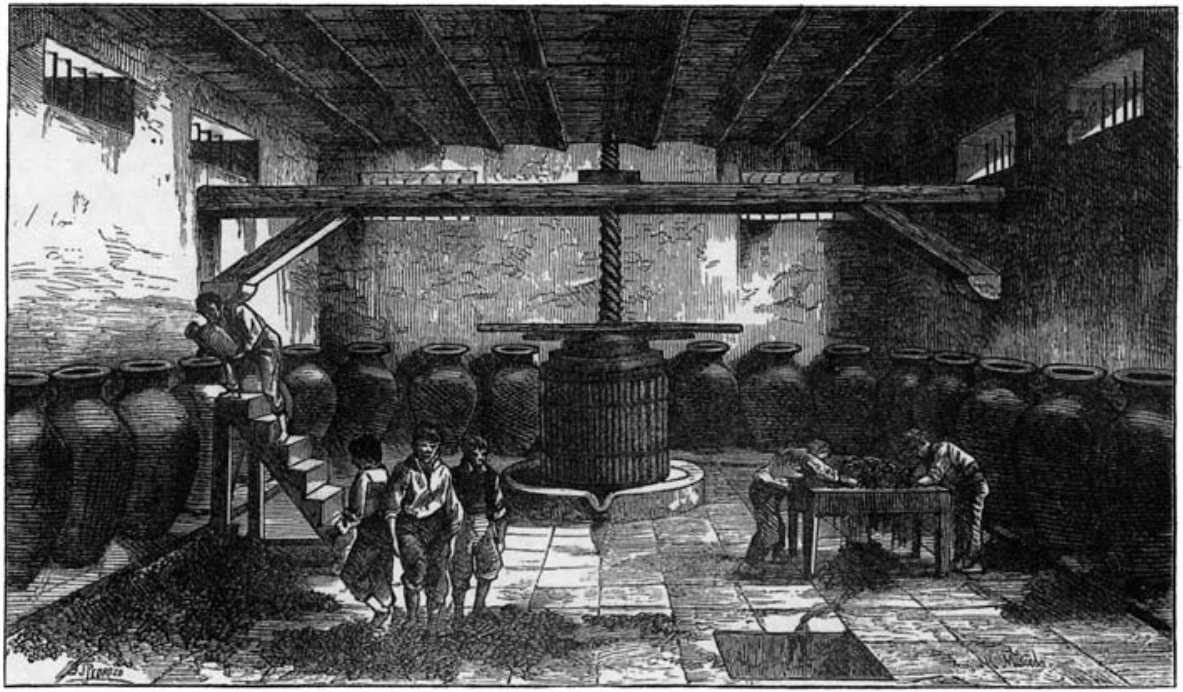

Figura 8 - Desenho de um lagar de vinho do século XIX da autoria de J. Pedrozo.

(Publ. João Ignacio Ferreira Lapa, Technologia rural ou artes chimicas, agricolas e florestaes, $2^{\mathrm{a}}$ ed., Lisboa,

Typographia da Academia Real das Sciencias, 1874, p. 103) 